\begin{tabular}{|c|c|c|c|c|c|}
\hline MUNIBE Antropologia-Arkeologia & $n^{\circ} 68$ & $301-325$ & DONOSTIA & 2017 & ISSN 1132-2217 • elSSN 2172-4555 \\
\hline
\end{tabular}

\title{
De fortificación Andalusí a campo de batalla en el frente extremeño durante la Guerra Civil. Exhumación de un soldado en el yacimiento arqueológico de "Castillo de Argallén" (Península Ibérica)
}

\author{
From fortification Andalusí to battlefield in front extremeño during \\ the Civil War. Exhumation of a soldier in the archaeological site of \\ "Castle Argallén" (Iberian Peninsula)
}

PALABRAS CLAVES: inhumación, frente de guerra, trincheras, arqueología del conflicto, antropología forense. GAKO-HITZAK: ehorzketa, gerrako frontea, lubakiak, gatazkaren arkeologia, auzitegiko antropologia.

KEY WORDS: inhumation, war landscape, trenches, conflict archaeology, forensic anthropology.

\section{Antonio José DOMÍNGUEZ (1), María FORTUNA(2), Antonio Doroteo LÓPEZ-RODRIGUEZ ${ }^{(3)}$ y Diego SANABRIA MURILLO(4)}

\section{RESUMEN}

La localización arqueológica de un soldado de la Guerra Civil Española entre los paramentos de una fortificación andalusí ha servido como vínculo interpretativo a través del tiempo de las ocupaciones militares de un mismo enclave geográfico. Este escenario comprende el llamado "Castillo de Argallén", en el término municipal de Campillo de Llerena (Badajoz) y su estudio se muestra en el presente trabajo como fundamental para la comprensión del dominio musulmán en la Baja Edad Media de Extremadura. En paralelo, los vestigios del paisaje de guerra documentados que rodean la inhumación del soldado y el estudio de su propia materialidad, complementan la descripción de lo que ocurrió y apuntan las carencias que aún hoy arrastra el estudio arqueológico de la Guerra Civil Española en Extremadura y el tratamiento de los "desaparecidos" por parte del Estado Español.

\section{LABURPENA}

Gotorleku andalustar bateko paramentuen artean Espainiako Gerra Zibileko soldadu baten lokalizazio arkeologikoa izan da kokapen geografiko berean izandako okupazio militarren denboran zeharreko interpretazioa egiteko lotura. Toki horretan dago "Argallén gaztelua" deitzen zaiona, Campillo de Llerena (Badajoz) udalerrian, eta hori aztertzea funtsezkotzat hartzen da lan honetan Extremadurako Behe Erdi Aroan musulmanen nagusitasuna ulertzeko. Modu paraleloan, soldaduaren ehorzketa inguratzen duten dokumentatutako paisaia-aztarnek eta materialtasunaren beraren azterketak osatzen dute gertatu zenaren deskribapena eta oraindik ere Espainiako Gerra Zibilaren azterketa arkeologikoak Extremaduran dituen gabeziak eta Espainiako Estatuak “desagertuei” emandako tratamendua agerian uzten dituzte.

\section{ABSTRACT}

The archaeological location of a Spanish Civil War soldier among the surfaces of an Andalusian fortification has served, through the time, as an interpretative link of the military occupations of the same geographic enclave. This setting comprises the so-called "Castillo de Argallén", in the municipality of Campillo de Llerena (Badajoz) and its study is shown in the present work as fundamental for the understanding of the Muslim domain in the Late Middle Ages of Extremadura. In the same way, the remains of the documented war landscape, which surround the burial of a republican soldier and the study of their own nature, complement the description of what happened and point to the lack still dragged by the archaeological study of the Spanish Civil War in Extremadura and the treatment of "missing people" given by "Spanish State"

The archaeological intervention is part of a plan of action in the long term oriented to the revaluation of the archaeological patrimony of the regions where they settle. The works are located between the region of La Serena and the Campiña Sur (Badajoz), in the Sierra de Argallén. This geographical formation is located in the South East of Extremadura, establishing itself as a dividing line between the aforementioned regions. Its elevation has allowed an exceptional visual control between two territories that throughout history have acquired an own identity. This strategic position has been the one that turns this enclave into a spectacular one, which has been accumulating in it key remains when we try to understand both the surrounding territory and the historical events that modified it.

The main objective of the archaeological intervention consisted of an approach to the sequence stratigraphic of the site. This approach meant the realization of two probes - PROBES A and B-, located in the highest areas of the site, taking advantage of the presence of a large concentration of structures. The general results of this campaign show the presence of a long cultural sequence. We can also say that we are facing a first-rate location for its role in different historical events, especially during the "Reconquista" and later resettlement of these regions, as well as in the Civil War.

\footnotetext{
(1) Arqueólogo, Asociación para el Estudio y Recuperación del Patrimonio Bélico reciente "Frente Extremeño" (ajdomin@hotmail.com; C|Padres $n^{\circ}$ 16. Higuera de la Serena, Badajoz. C.P- 06441).

(2) Antropóloga forense, Asociación para el Estudio y Recuperación del Patrimonio Bélico reciente "Frente Extremeño".

(3) Historiador, Asociación para el Estudio y Recuperación del Patrimonio Bélico reciente "Frente Extremeño".

(4) Arqueólogo, Asociación para el Estudio y Recuperación del Patrimonio Bélico reciente "Frente Extremeño"
} 


\section{1.- INTRODUCCIÓN}

Seguramente las tropas moras, un tabor y regulares, que tomaron al asalto las posiciones republicanas del Ilamado "Castillo de Argallén" en febrero de 1938 desconocían que estaban reconquistando un antiguo asentamiento musulmán. El rastro material de la Historia sale a la superficie con cada sondeo que los arqueólogos realizan en la cresta de mayor altura de la "Sierra de los Argallenes". Su elevación ha permitido un control visual excepcional entre dos territorios que a lo largo de la Historia han adquirido una identidad muy marcada como son la comarca de La Serena y la Campiña Sur. Esa posición estratégica ha sido la que convierte a este enclave de la Sierra de los Argallenes en un espectacular ejemplo de palimpsesto arqueológico, donde el cerro como si fuera un antiguo pergamino cientos de veces reaprovechado en el tiempo, acumula vestigios claves a la hora de interpretar tanto el territorio que lo circunda como los acontecimientos históricos que lo modificaron.

\section{GESTIÓN DEL PROYECTO, RECURSOS HU- MANOS Y MEDIOS MATERIALES}

La intervención arqueológica denominada "PROYECTO ARQUEOLÓGICO EN EL CASTILLO DE ARGALLÉN EN CAMPILLO DE LLERENA (BADAJOZ).", forma parte de un plan de actuación a largo plazo orientado a la revalorización del patrimonio arqueológico en el término municipal de Campillo de Llerena.

El interés científico está fuera de toda duda, dado que nos encontramos con un yacimiento arqueológico con una secuencia ocupacional muy dilatada, situada entre los albores de la romanización (al menos) y la época contemporánea, especialmente durante la Guerra Civil española, con un importante pasado andalusí. Un enclave de gran extensión que aúna, por una lado, gran cantidad de restos apreciables a simple vista, y que se imbrican formando un ejemplo espectacular de palimpsesto arqueológico, y por otro su incomparable marco ambiental, al encontrarse enclavado en una sierra casi inaccesible con un amplio dominio visual. Por todo ello consideramos del máximo interés efectuar una lectura arqueológica del lugar, teniendo en cuenta además al "vacío" científico que existe aún en el cuadrante SW de la Península Ibérica en yacimientos fortificados con un pasado tan dilatado y que permanecen "olvidados" en muchas sierras del ámbito rural.

En cuanto a la puesta en marcha del Proyecto, la iniciativa surge del Excmo. Ayuntamiento de Campillo de Llerena, y desde éste se comienza a trabajar una vez se cuenta con los permisos de los propietarios. Por su parte, dicho Ayuntamiento aportó el material necesario para la excavación y un vehículo para acceder al lugar, mientras que desde el Instituto de Arqueología de Mérida ${ }^{1}$ se aportó apoyo técnico facilitando un nivel óptico, una estación total y la documentación fotográfica relativa a la corrección ortogramétrica.

Debido a la inexistencia de presupuesto económico, se creó un grupo de técnicos de la zona, que de manera totalmente altruista llevaron a término los trabajos. La iniciativa para desarrollar éste proyecto partió de Francisco Martín Portalo, que como técnico A. D. L. E. en el Ayuntamiento se convirtió en su propulsor; por otro lado los arqueólogos de campo fueron Diego Sanabria Murillo, Francisco Portalo Núñez, Raquel Arroyo Trenado, Enrique Sánchez Carpintero, Francisco Martín González, José Ignacio Jiménez Gordon y Antonio José Domínguez Martín, este último Director Arqueológico. El dibujo de materiales corrió a cargo de Diego Sanabria Murillo, Itsaso de Rey Tena y Antonio José Domínguez Martín. Tanto el estudio de material arqueológico como el dibujo y la elaboración de planimetrías fueron ejecutados por Diego Sanabria Murillo y Antonio José Domínguez Martín. El estudio antropológico forense fue realizado en la Facultad de Medicina de la Universidad Complutense de Madrid por María Fortuna Murillo, María Benito Sánchez y el Dr. José Antonio Sánchez Sánchez; Mientras que el estudio histórico fue desarrollado por Antonio D. López-Rodríguez.

\section{LA INTERVENCIÓN ARQUEOLÓGICA}

Los trabajos se sitúan en el yacimiento arqueológico del Castillo del Argallén, localizado en la sierra homónima, entre las Comarca de la Serena y la Campiña Sur (Badajoz) (Figs. 1 y 2). Esta formación geográfica se ubica en el SE de Extremadura, estableciéndose como línea divisoria entre las comarcas ya citadas. La sierra concurre como un ramal de la de Peraleda, una formación armoricana de cuarcitas orientadas de $\mathrm{N}$ a S. Es una zona de abundantes dehesas donde predominan los suelos pardo-rojizos meridionales, y en cuyos espacios abiertos se alternan zonas de cultivo de cereal con pastos de aprovechamiento ganadero. El paisaje queda definido así por una orografía donde los llanos y las ondulaciones van cediendo lugar a un terreno más accidentado, y es aquí donde predomina un paisaje de bosque mediterráneo en las zonas no roturadas, coincidentes con las sierras y algunas rañas. Este bosque se identifica con una formación vegetal constituida fundamentalmente por un estrato arbóreo de encinas; con jaras, escobas, brezos, cantuesos, madroños y otras especies arbustivas, además de la repoblación de eucaliptos. Todo ello aparece surcado por abundantes arroyos, como el de Santa María y el Argallén, por citar los más próximos, tributarios todos del río Guadámez, auténtico eje vertebrador de la zona.

\footnotetext{
${ }^{1}$ Agradecemos la colaboración a D. Victorino Mayoral Herrera.
} 


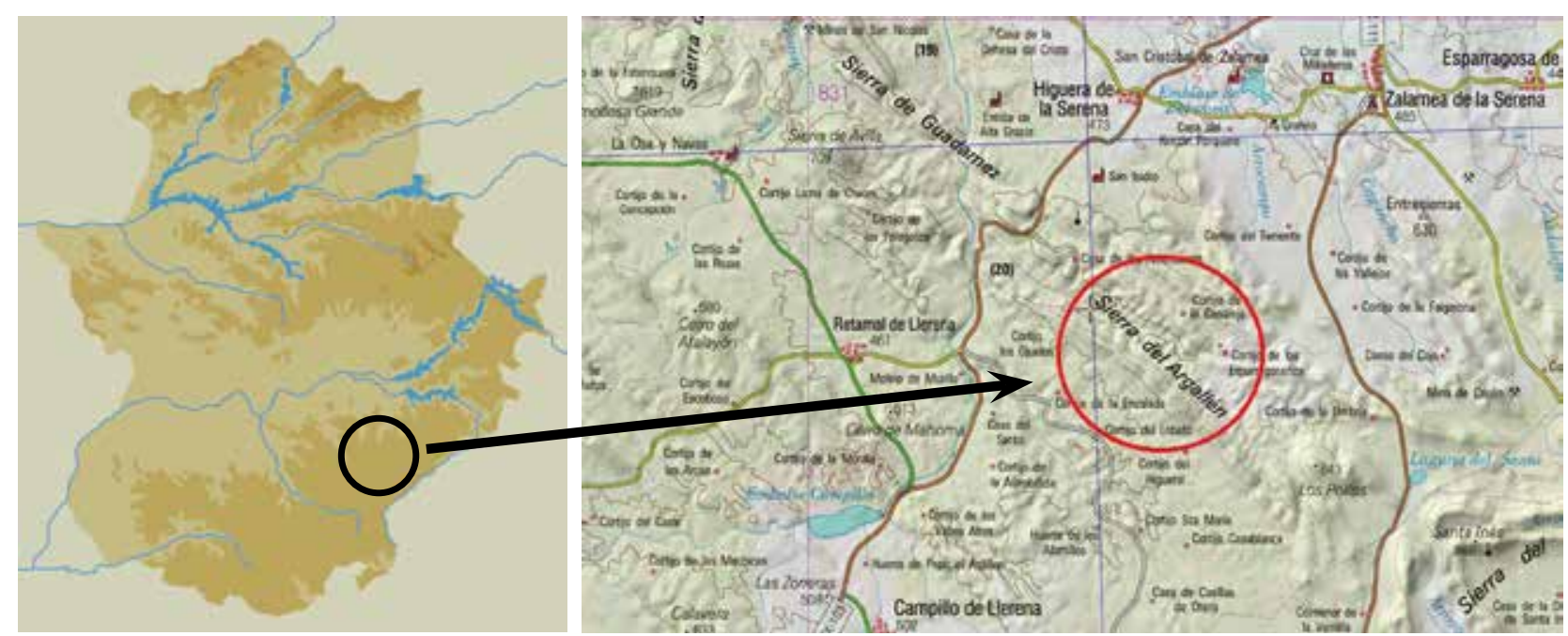

Fig. 1, 2. Mapa físico de Extremadura y localización de la Sierra de Argallén. Fuente: SIGPAC. / Map of Extremaduratation of the zone of the 2016 finds and Location of the Sierra de Argallén. Source: SIGPAC.

El objetivo principal de la intervención arqueológica consistía en una aproximación a la secuencia estratigráfica del yacimiento del Castillo del Argallén, un planteamiento que pasaba obligatoriamente por la realización de sondeos. Dadas las limitaciones económicas, el número de sondeos arqueológicos se limitó a dos -Sondeos A y B-, situados en las zonas más elevadas del yacimiento, aprovechando la presencia de una gran concentración de estructuras (Fig. 3). En este sentido, se optó por realizar los sondeos a partir de la cara interna de dos potentes muros ciclópeos, con la esperanza de llegar a la base de los mismos y obtener algún dato sobre la fundación de ambos paramentos, a nuestro juicio un objetivo de gran importancia. En cuanto al sistema de registro se ha utilizado el desarrollado por Harris (1991) con base de documentación en Unidades Estratigráficas.

El Sondeo A se proyectó en la misma cima de la Sierra -coordenadas UTM X 261172 / Y 4273238; Da- tum ED50, Huso 30- sobre una de sus estructuras más visibles, un lugar donde aparentemente se conservaba bastante potencia sedimentaria y donde dicha estructura conserva un alzado considerable (Fig. 4). Este

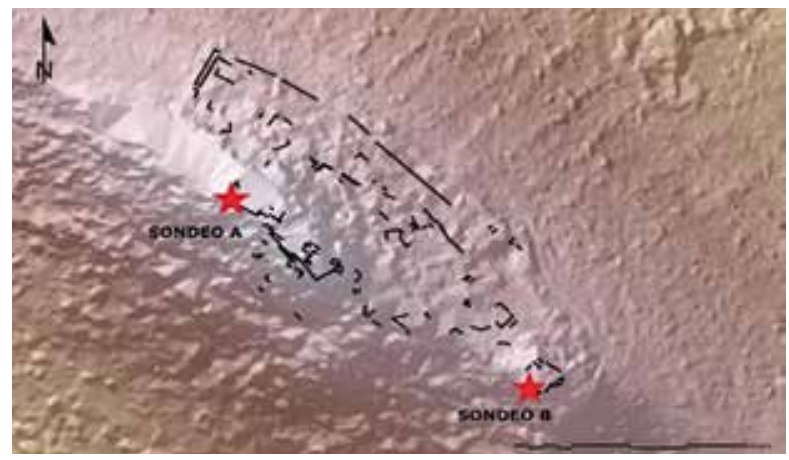

Fig. 3. Planta general de estructuras visibles en superficie y localización de ambos sondeos / Overall plant of visible structures and surface location of both soundings. (s. Victorino Mayoral Herrera).

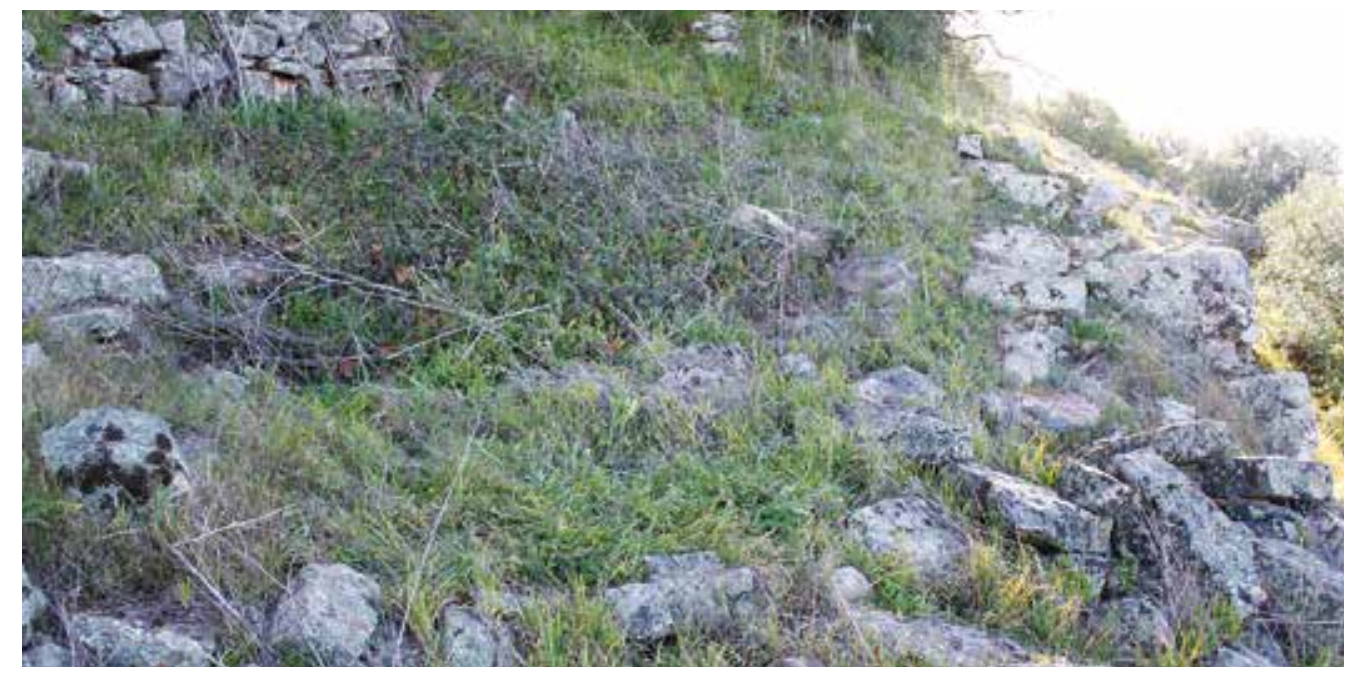

Fig. 4. Aspecto inicial del Sondeo A. A la izquierda, parapeto contemporáneo. A la derecha, muro andalusí. / Initial appearance of sounding A. On the left, contemporary parapet. On the right, andalusí wall. 
sondeo de $4 \times 3 m$, lo trazamos en la cara interior de este muro, de manera que pudiésemos documentar su fábrica y los estratos asociados a ella.

Por su parte, El sondeo B lo trazamos en el interior de una de las estructuras más significativas situadas en la ladera SE del yacimiento -coordenadas UTM $X$ 261317 / Y 4273143; Datum ED50, Huso 30-. Este sondeo tiene unas medidas de $2 \times 2 \mathrm{~m}$ y a priori ofrecía una potencia sedimentaria considerable (Fig. 5). Al igual que el sondeo $A$, éste se enmarca en el interior de dos muros que forman esquina.

\subsection{Resultados generales}

Como resultados generales de esta campaña podemos indicar la presencia de una dilatada secuencia cultural. En primer lugar, hay que hacer referencia a una serie de materiales que apuntan a una ocupación del sitio a caballo entre el mundo indígena y la romanización. Es difícil precisar todavía si este primer conjunto artefactual responde a niveles de ocupación prerromanos, ya que aparecen removidos e integrados en estratos andalusíes. Lo que sí es evidente es que se trata de materiales presentes en contextos prerromanos bien estudiados del entorno cultural del yacimiento, entendido éste como la Beturia Túrdula, del que son buenos ejemplos los yacimientos como Entrerríos, Tabla de las Cañas o El Espadañar (Rodríguez Díaz et al., 2012; Domínguez de la Concha y García Blanco, 1992; Sanabria Murillo, 2013), aunque su hallazgo en niveles andalusíes hace que estas conclusiones deban ser tomadas con las debidas reservas. Por un lado, la ausencia de "fósiles directores" propios de este momento -producciones de barniz rojo ibérico, importaciones griegas- y, por otro lado, la pre- sencia de dos perfiles cerámicos romanos -olla y mortero- en el mismo estrato, nos llevan a contemplar también la posibilidad de una proximidad de estos materiales a contextos situados entre las postrimerías republicanas y el siglo I d.C., precisión cronológica que sí es clara en las intervenciones llevadas a cabo en recintos torre y oppida cercanos al Argallén (Ortiz Romero, 1991).

Esta campaña de sondeos también nos ha permitido documentar la fundación de algunos de estos paramentos "ciclópeos" en época andalusí. En ambos sondeos se ha constatado una ocupación intensa en este período, principalmente entre las Primeras Taifas y el mundo almohade, posiblemente hasta su absorción del sitio en territorio cristiano y su definitiva despoblación en el siglo XIII. Con todo, la construcción de potentes paramentos de carácter "ciclópeo" se fundamenta en la creación de muros ataludados al exterior con zapata de nivelación al interior, mediante la disposición de enjarjes de piedra muy amplios que funcionan tanto como plataforma horizontal, cimiento y trabazón del muro al interior, salvando así el elevado desnivel del lugar. En todo caso, el registro material no aporta ningún dato acerca de una continuidad del hábitat ya en época cristiana, por lo que se confirma la despoblación del sitio una vez conquistado el territorio, quedando como vértice del deslinde entre las órdenes de Alcántara y Santiago. En todo caso, la amplia dispersión de los materiales cerámicos y de las estructuras visibles y su entidad, así como la presencia de murallas y posibles torres, hacen suponer la importancia que el "Algalet" andalusí debió tener en la Extremadura musulmana: un hisn comparable a los cercanos de Magacela, Hornachos o Benquerencia de la Serena (Gibello Bravo, 2006), que por distintas razones no se reocupó tras la conquista cristiana, como sí ocurrió con los hisn vecinos.

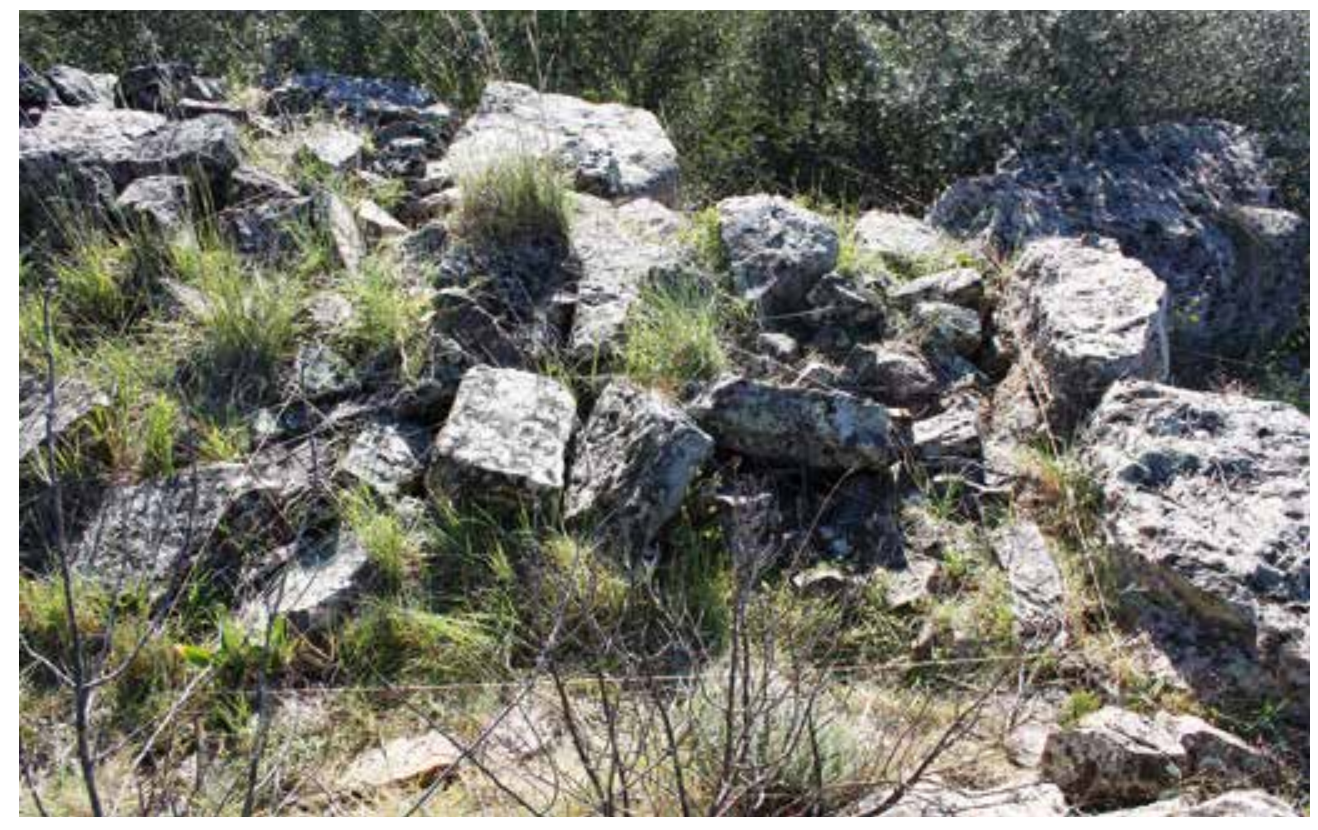

Fig. 5. Sondeo B. Nivel superficial. El conjunto de mampuesto pertenece a los restos del parapeto contemporáneo. / Sounding B. Surface level. The set of masonry belongs to the remains of contemporary parapet. 
Finalmente, se ha documentado un importante nivel contemporáneo que se encuadra en el contexto de la Guerra Civil Española (1936-1939). De esta forma, los importantes restos constructivos de la fase medieval se readaptan y aprovechan ante nuevas necesidades, por lo que el lugar es testigo directo del último acontecimiento bélico, hecho que ha dejado una notable huella en el yacimiento (Fig. 6).

\subsection{Los restos contemporáneos: la Guerra Civil}

Dadas las características físicas de la Sierra del Argallén, con una altura en torno a los 750 ms.n.m, con un gran dominio visual y una particular inaccesibilidad, el enclave fue elegido para disponer en él un importante conjunto de fortificaciones durante la Guerra Civil, ya visibles antes de realizar los sondeos. De este modo, podían y pueden observarse trincheras, parapetos, pozos de tirador, refugios antiaéreos, etc. Por supuesto las zonas elegidas para ubicar los sondeos no escapaban a esa presencia de estructuras vinculadas al mundo bélico. Por su parte, al $\mathrm{N}$ del Sondeo A se levanta un parapeto de piedra y barro que protege a una trinchera, mientras que al $\mathrm{N}$ del Sondeo B se localizaba los restos de un parapeto de piedras trabadas en seco.

En el primero de los casos, en el Sondeo A, se pudo documentar esta fase contemporánea a través de dos niveles. El primer estrato correspondía a la cubierta vegetal o nivel superficial (U.E 100), muy orgánico, de 10 a $15 \mathrm{~cm}$ de potencia. En esta capa aparecen abundantes restos cerámicos de diferentes épocas destacando un botón de nácar del que se hablará más adelante.

Documentada la U.E 100 (cubierta vegetal), el siguiente nivel es mucho más compacto, integrado por piedras cuarcíticas de mediano y gran tamaño y tierra. La matriz de este nivel es arenosa, de color marrón claro y de potencia variable $(35-40 \mathrm{~cm})$. En él aparecen fragmentos de restos cerámicos, material constructivo, adobes, carbones, un proyectil (proyectil $n^{\circ} 1$ ) y una vaina (vaina $n^{\circ} 1$ ), fechados ambos en la Guerra Civil. A este estrato le denominamos como U.E 101 (fig. 7), y lo identificamos como un gran derrumbe procedente de estructuras cercanas realizadas durante dicho conflicto bélico. Bajo este gran derrumbe (U.E 101), localizamos la siguiente unidad estratigráfica, a la que designamos como UE 102. La matriz de este nivel es arenosa, de color marrón oscuro muy homogénea y de potencia variable. El nivel se encuentra muy alterado, y en él aparecen numerosos fragmentos cerámicos de diferentes periodos históricos, material constructivo como adobes, carbones, una concha, un fragmento de cristal azul y una lasca de sílex fragmentada, seis vainas y un proyectil (proyectil $N^{\circ} 2$ ). Una vez retirado parte del nivel identificado como U.E 102, delimitamos una zanja de

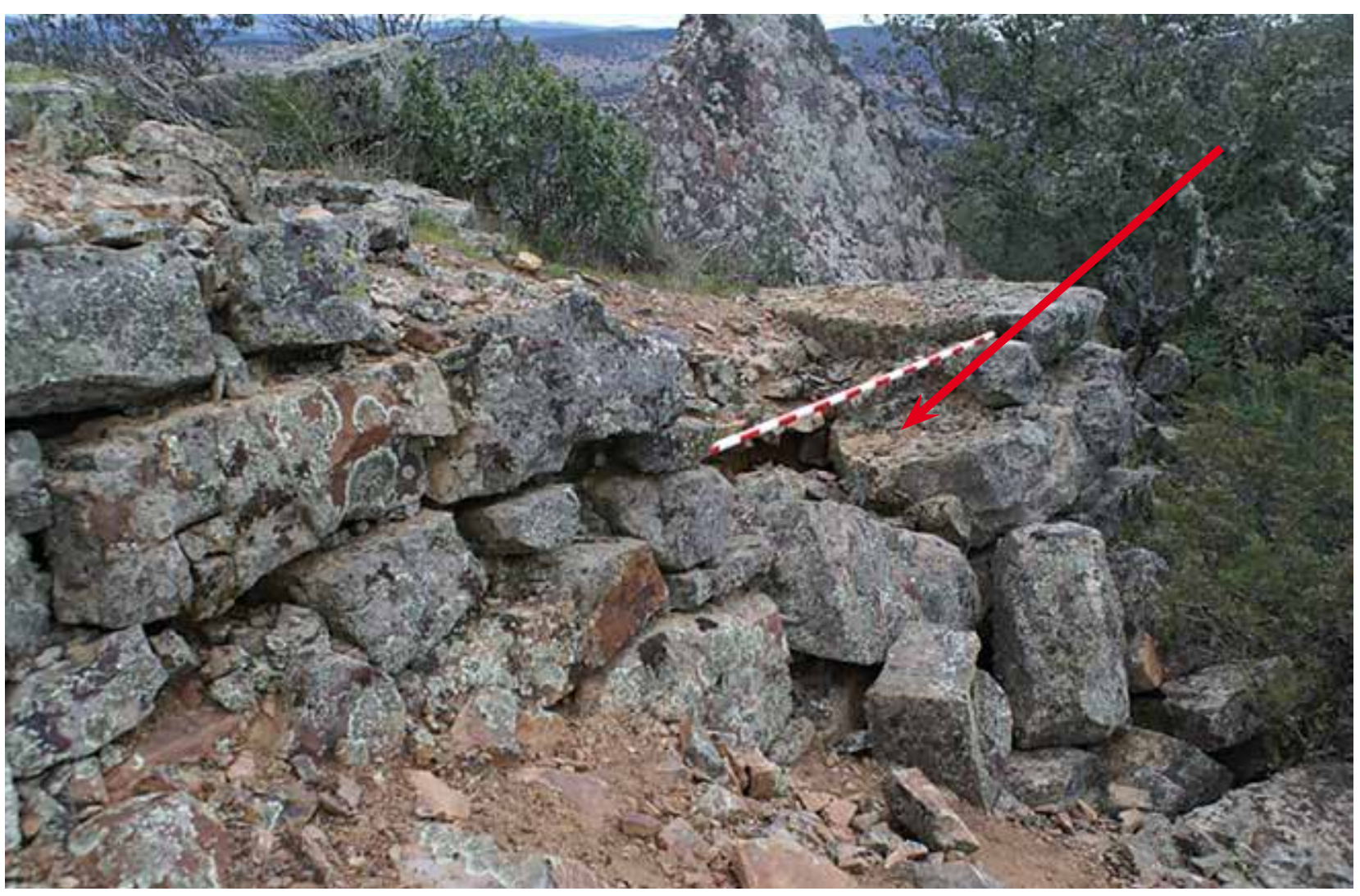

Fig. 6. Posible impacto de artillería contemporánea sobre un paramento de época andalusí. / Possible impact of contemporary artillery on an Andalusian period ornament. 


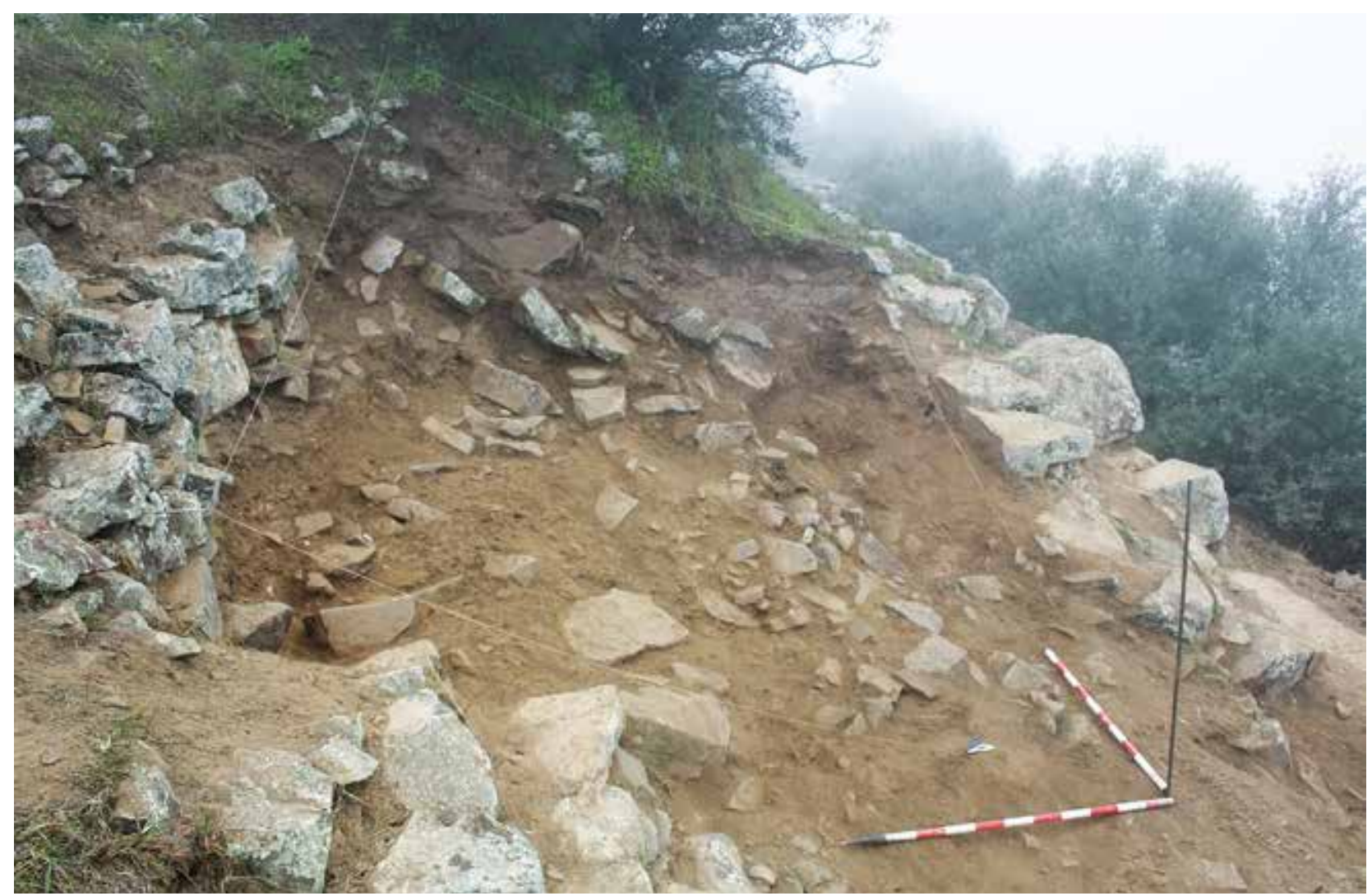

Fig. 7. Unidad de derrumbe U.E 101. / Collapse Unit U.E 101.

un metro de ancho, paralelo al muro andalusí (U.E 97), a efectos de "microsondeo", y que nos permitió conocer la cimentación de dicho muro a base de un aterrazamiento de grandes piedras, careadas al exterior. Esta zanja también nos permitió comprobar cómo durante la fase contemporánea (Guerra Civil) se habían alterado los niveles andalusíes hasta los cimientos: la construcción del parapeto de trinchera situado inmediatamente al $\mathrm{N}$ implicó la remoción de tierras para obtener piedra para construirlo, provocando así una importante depresión o cubeta justo donde situamos nuestro sondeo. La retirada de mampuesto y tierra dejó al descubierto el aterrazamiento andalusí, sirviendo la depresión ocasionada como pozo de tirador, con una inmejorable visibilidad y dominio del entorno, pozo cuya base era el propio aterrazamiento andalusí (Fig. 8).

Finalmente, la zanja también procuró el hallazgo más importante, en el extremo $\mathrm{W}$ de la misma (Fig. 9 y 10). Así, localizamos en la esquina suroeste del sondeo A diferentes restos óseos humanos fragmentados: una mandíbula y la parte superior del cráneo. Todos estos indicios nos indicaban que posiblemente se tratara de una fosa de la Guerra Civil (1936 -1939) en relación con el Frente Extremeño. Se ubicaba en parte fuera del sondeo propuesto, por lo que pusimos estos datos en conocimiento de la Consejería de Cultura, que permitió la ampliación del sondeo para documentar el hallazgo en su totalidad (Fig. 11). La unidad estratigráfica diferen- ciada que albergaba los restos óseos se denominó U.E 104, formada por un nivel arenoso de color marrón oscuro de potencia variable. Dicho estrato se encontraba muy alterado y en él se localizó un elevado número de cerámicas de diferentes épocas, procedentes de esas remociones a las que antes aludíamos, restos de vestimenta y calzado, y un importante número de metralla y munición.

En cuanto a los niveles contemporáneos en el Sondeo B, éstos se corresponden con las UE's 199 y 202, un parapeto de piedra trabada a hueso y el derrumbe del mismo respectivamente. Los parapetos son una estructura común en el yacimiento, y en este caso en concreto se aprovecha la presencia de estructuras anteriores (UE 200) para apoyarse en ellas (Fig. 12). Al retirar la U.E 202 apareció un nivel de cubierta vegetal identificada como U.E 203, integrada por sedimentos muy orgánicos de color marrón oscuro y baja compactación, de 15 a $25 \mathrm{~cm}$ de potencia. Esta capa estaba muy alterada debido al derrumbe del parapeto de la Guerra Civil, que tuvo lugar sobre el suelo vegetal de ese momento, apareciendo bajo ese estrato una vaina de munición. A partir de este nivel, nos encontramos con distintos paquetes sedimentarios, un pavimento de tierra apisonada, un tabique de compartimentación y el mismo sistema de aterrazado documentado en el Sondeo A. Todas estas unidades estratigráficas se fechan en cronologías andalusíes, entre los siglos XI y XII. 


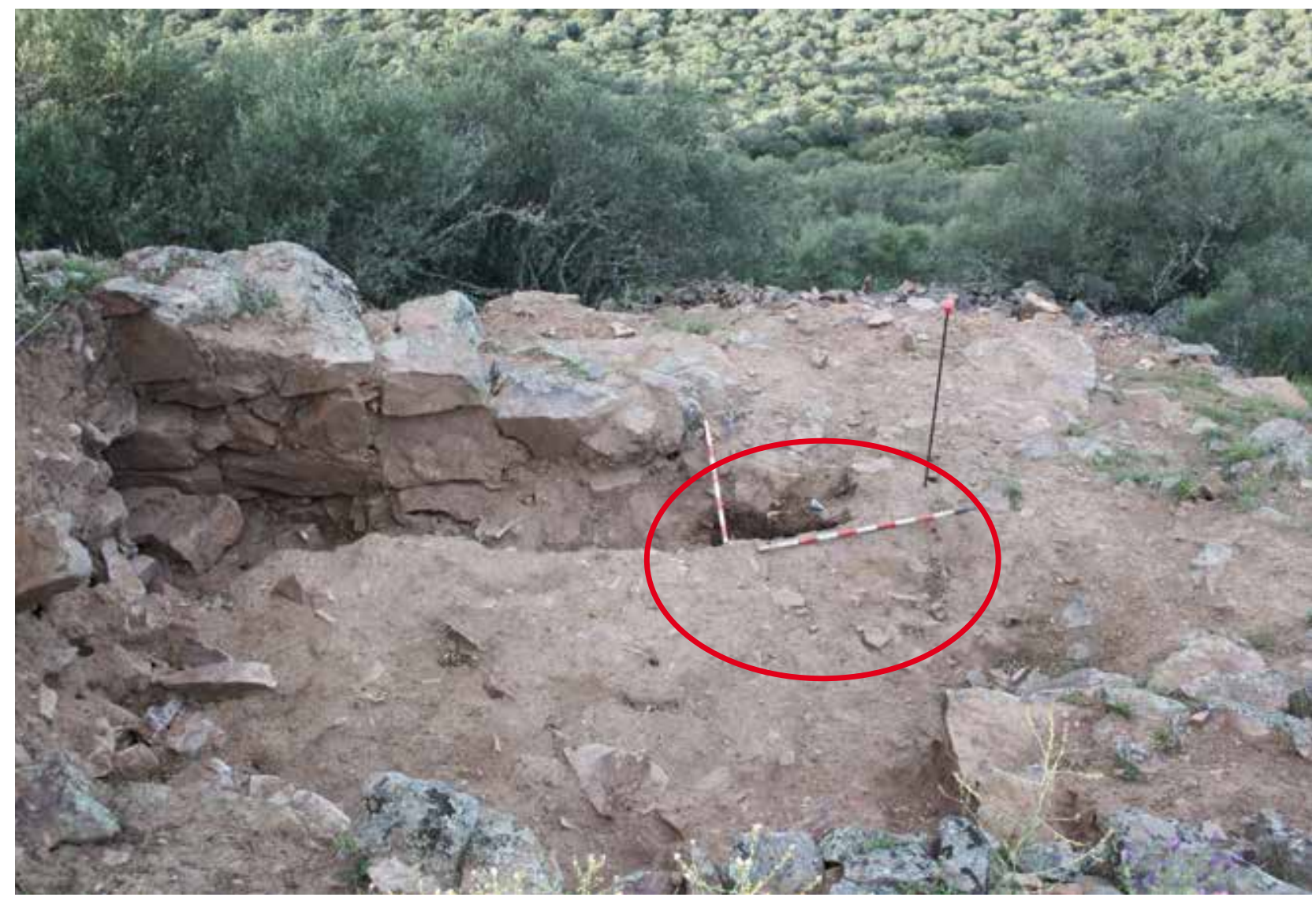

Fig. 8. Sondeo A. Vista desde el N hacia el S. Al fondo, muro andalusí UE 97 y delante de éste el "microsondeo". El círculo señala la zona donde se produjo el hallazgo de los restos óseos. / Sounding A. View from the N. to the S. In the background, UE 97 andalusí wall and in front of it the "microsounding". The circle indicates the area where there was the discovery of the skeletal remains.
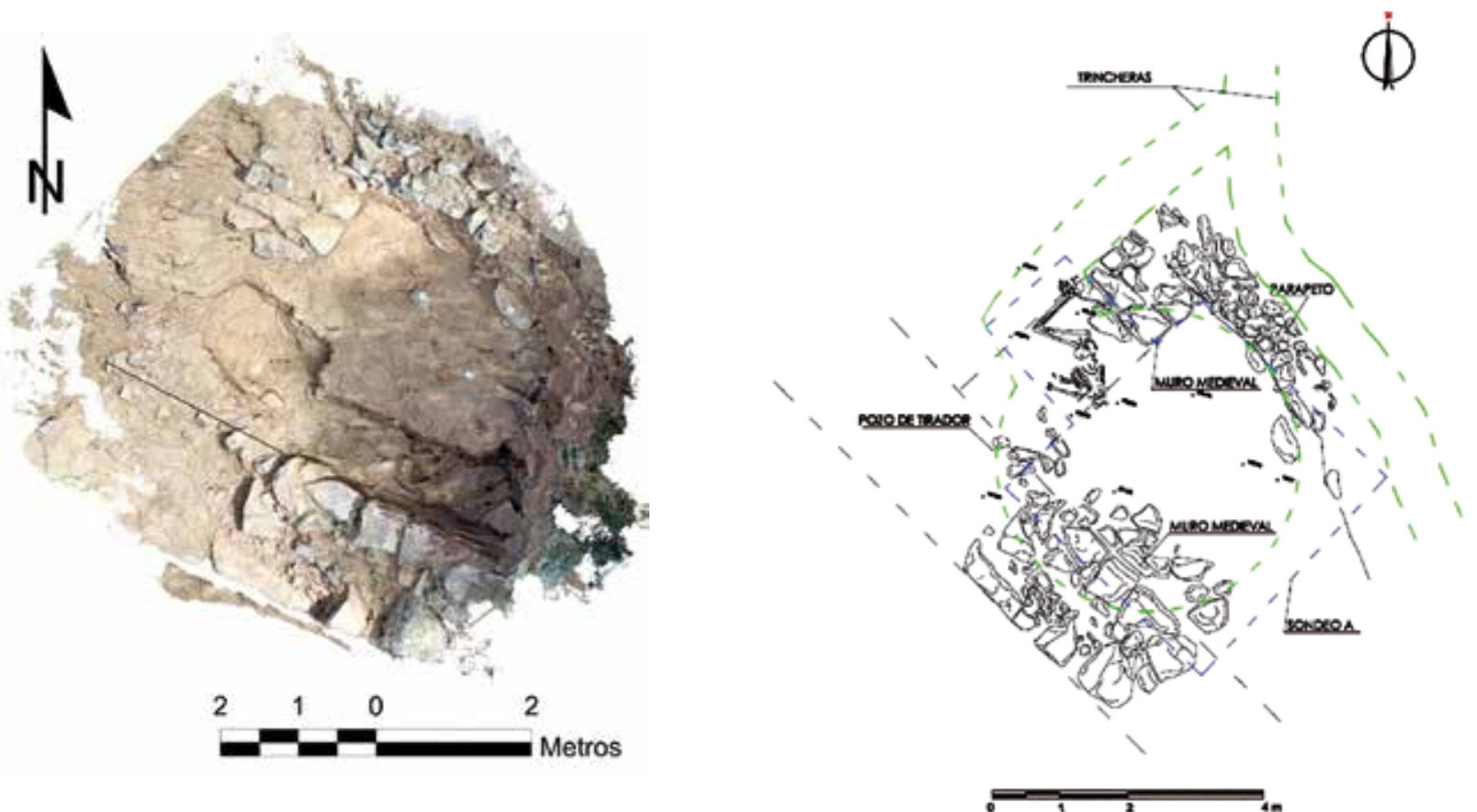

Fig. 9, 10. Planta del Sondeo A. Izquierda: imagen con corrección ortogramétrica (s. Victorino Mayoral Herrera). Derecha: Planta-esquema (s. Diego Sanabria Murillo). / Plant of sounding A. Left: image with ortogrametric correction (s Victorino Mayoral Herrera.). Right: Ground-scheme (s Diego Murillo Sanabria.). 


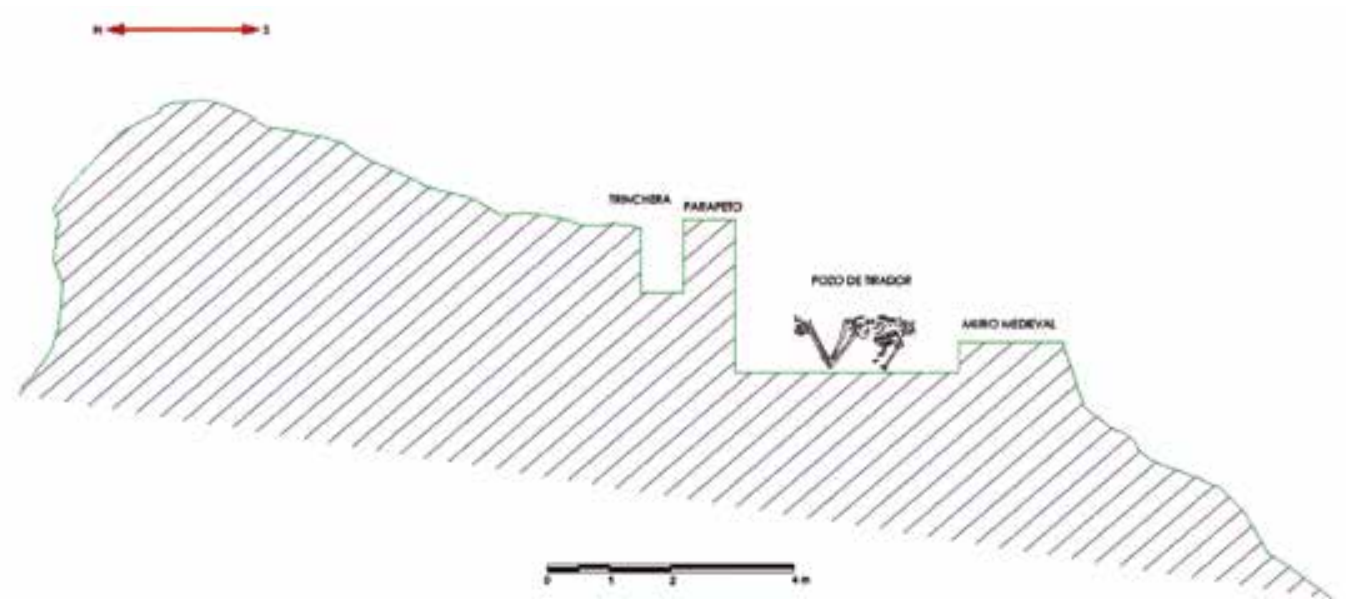

Fig. 11. Sección-esquema N-S del Sondeo A. $/$ Section-scheme N-S of sounding $A$.

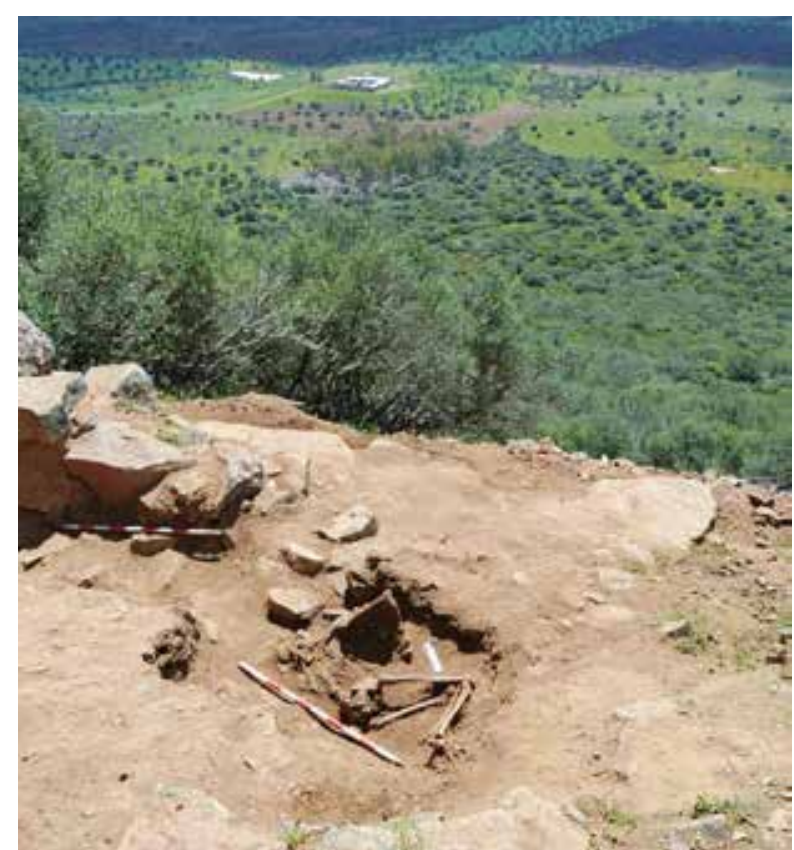

Fig. 12. Localización de la inhumación en el sondeo A. / Location of burial in the sounding $A$.

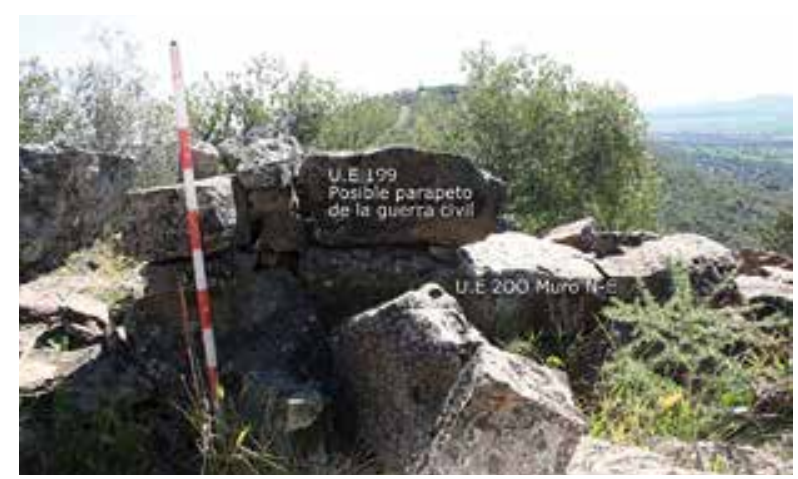

Fig. 13. Detalle del parapeto desde el W. / Detail of parapet from the W.

\footnotetext{
2 Ver esquemas en epígrafe 3.2
}

\subsection{Las estructuras arqueológicas}

La superficie intervenida mediante los dos sondeos realizados impide reconocer en extensión cualquier tipología de estructura arqueológica que superase los límites del sondeo. Más allá de las construcciones de época andalusí a las que antes nos referíamos, también se ha documentado parte de una de una estructura directamente relacionada con el último acontecimiento bélico identificada con un pozo de tirador ${ }^{2}$. Por otro lado, ya fuera de los sondeos, un simple reconocimiento ocular del entorno permite reconocer muchos más elementos defensivos como trincheras, parapetos, aspilleras o refugios antiaéreos.

Respecto al pozo de tirador, se trata de una construcción defensiva resultante de largos períodos de tiempo en las "guerras de posición" (Fig. 14). El pozo proporciona seguridad y un amplio campo visual y de tiro, resguardo por un parapeto de tierra y piedras y camuflado mediante elementos naturales como ramaje, etc. Estos pozos están unidos a otros pozos o trincheras principales mediante trincheras-ramales, y en este sentido, el pozo de tirador documentado en el Sondeo A debió conectarse con la trinchera que está por encima de éste. Normalmente, en este tipo de estructuras el tirador se encuentra tendido y ocasionalmente de rodillas (Adrada Fernández, 1939).

Como señalábamos, aunque no se han documentado otras estructuras contemporáneas de origen bélico en los sondeos, sí son visibles numerosas tipologías en las inmediaciones. De esta forma, hemos podido reconocer trincheras, parapetos, aspilleras y refugios antiaéreos (Figs. 15 y 16).

A falta de futuras intervenciones de mayor calado en el lugar, sólo conocemos dichos elementos en su manifestación superficial, que si bien están afectados por la ruina y el paso del tiempo, pueden reconocerse y diferenciarse a simple vista y sin problema. En todo caso se trata de elementos muy precarios, construidos casi precipitadamente y con materiales del lugar, desta- 


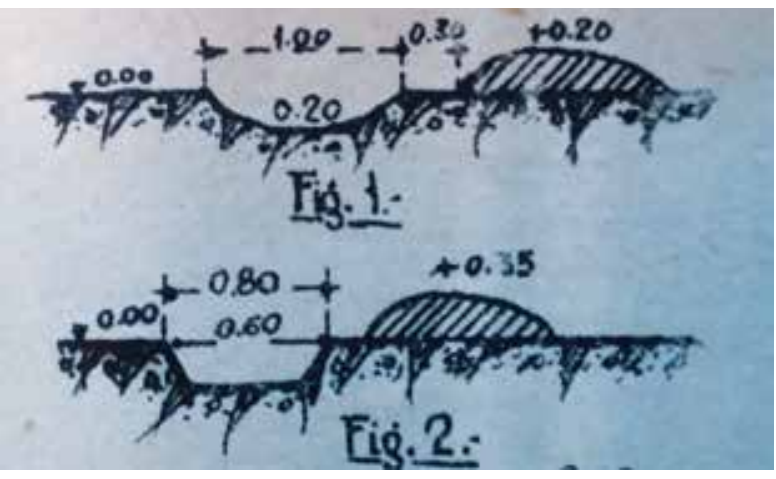

Fig. 14. Perfiles de pozo para tiradores tendidos (Fig.1) y de rodillas (Fig 2), s. Adrada Fernández (1939). / Well logs for lying shooters (Fig.1) and kneeling shooters (Fig. 2), s. Adrada Fernandez (1939).

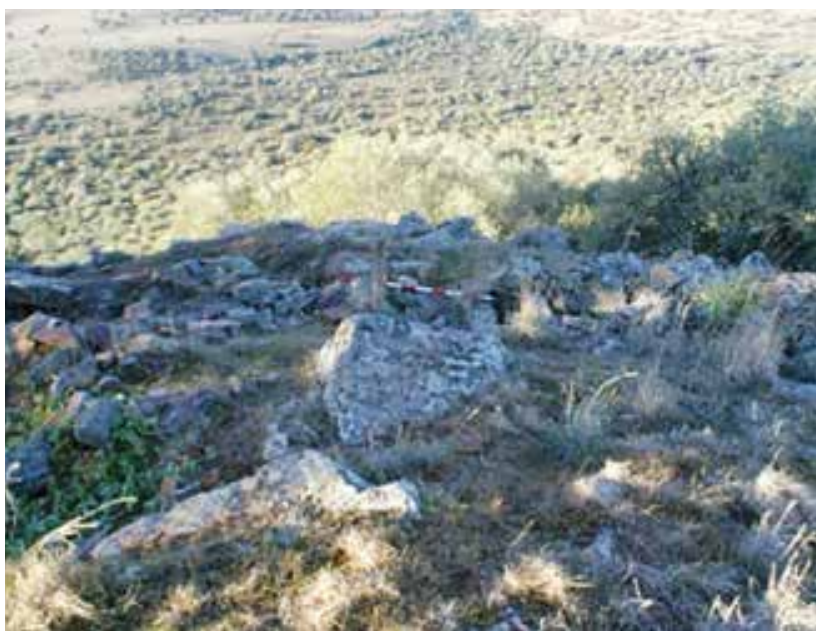

Fig. 15, 16. A la izquierda, trinchera inmediatamente por encima del pozo de tirador. A la derecha, parapeto con aspillera. / On the left, immediately trench above the foxhole. On the right, parapet with loophole.
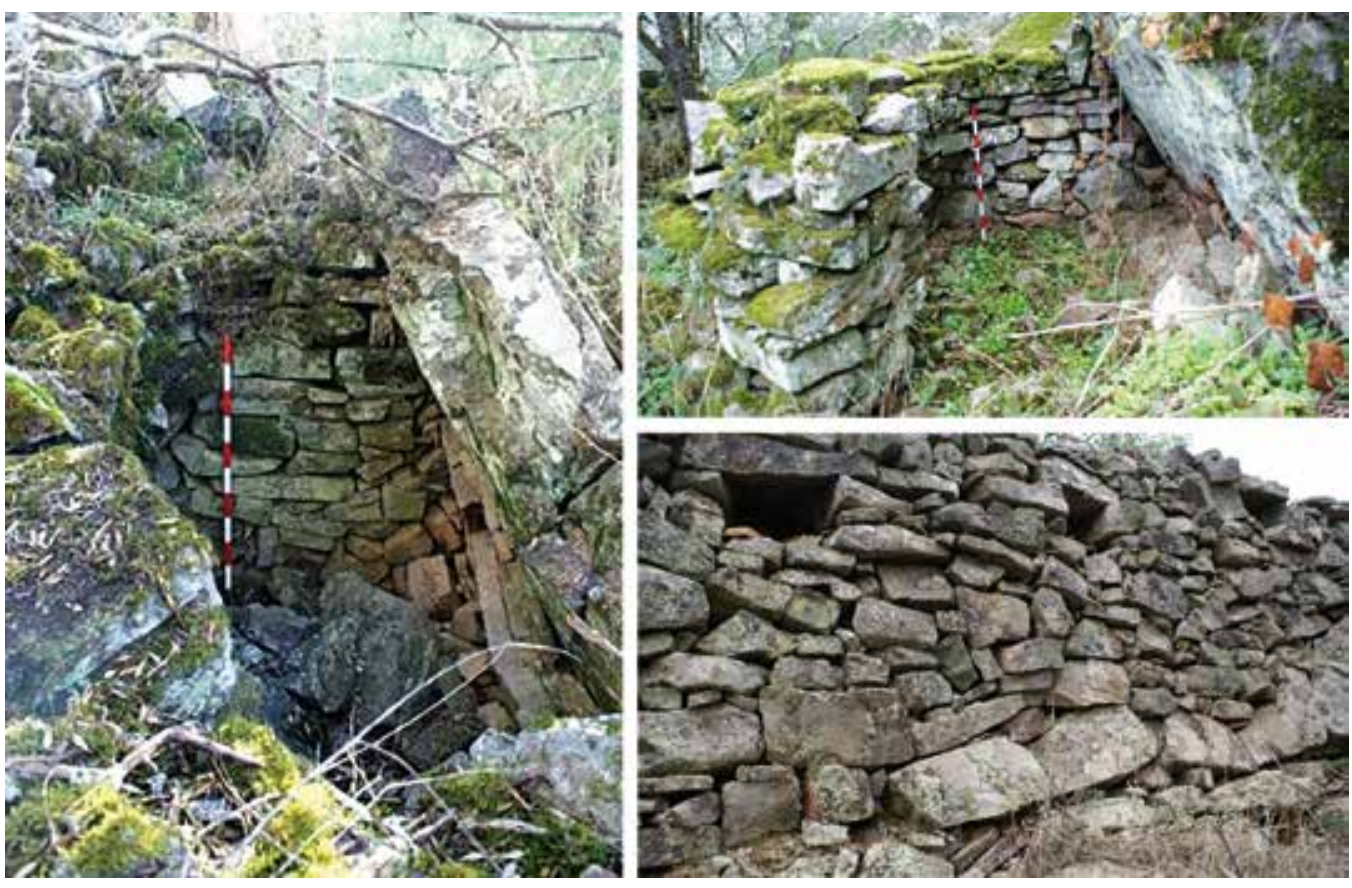

Fig. 17, 18, 19. Imágenes de refugio antiaéreo republicano en dos vistas y parapeto republicano con aspilleras. / Images of Republican air raid shelter in two views and Republican parapet with loopholes. 


\subsection{Estudio de los materiales arqueológicos propios de la Guerra Civil}

En relación a los materiales recogidos, adscritos al periodo vinculado a la Guerra Civil Española (1936 1939), durante la presente campaña (Fig. 27), tenemos que resaltar que el mayor volumen de restos militares lo representa sin duda alguna los vestigios de cartuchería y munición De ellos, la parte más importante está formada por casquillos de cartuchos. Así el elemento central de estudio es la cartuchería (vainas y proyectiles). Estos artefactos detectados se encuentran revueltos con los materiales andalusíes y prerromanos o de "tradición" indígena.

Destacamos de manera considerable la presencia de 16 vainas, cuyas condiciones generales de conservación son bastante buenas. De éstas, hemos podido reconocer de forma nítida un total de diez, de origen y procedencia variado. El resto no han podido ser identificadas ya que o no cuentan con el marcaje de identificación en la base o bien porque su avanzado estado de deterioro lo impide.

Las procedentes de México suponen el conjunto más abundante con un total de cuatro piezas (Fig. 20). Elaboradas en la Fábrica Nacional de cartuchos de México D.F. en 1930, que integran los siguientes calibres: $7 \times 57 \mathrm{~mm}$; 7x57/Mod.189; 7mm/Mauser español; 7mm/ Mauser mexicano; 7×56.75/Mauser brasileño. Su cartucho es de tipo ordinario, mientras que la bala presenta núcleo de plomo cubierto de acero y el material de la vaina es de latón. Por su parte, los marcajes son los siguientes: "FNC 7 m/m 1930" para la vaina $n^{\circ} 2$ recuperada en la U.E 102; y "MEXICO 7m/m 1930" en el caso de las vainas $n^{\circ} 8,9$ y 10 -U.E 105-.

Ejemplares similares a la vaina $n^{\circ} 2$ han sido localizados en La Batalla de Madrid (1936-39), en un embudo de artillería reaprovechado como un pozo de tirador y un refugio de Torrejón Velasco, ambos elementos adscritos al ejército republicano, que se sitúan cronológicamente entre el 29 de octubre y el 3 de noviembre de 1936, fechas de dos contraofensivas republicanas sobre el flanco derecho del dispositivo atacante de Valera sobre Madrid y la estabilización del frente, a mediados de noviembre de 1936, respectivamente (López Fraile et al., 2008).

En segundo lugar hemos recuperado dos vainas de procedencia nacional, localizadas en la U.E 105. Se trata de las vainas $n^{\circ} 11$ y $n^{\circ} 12$, fabricadas en la Pirotecnia de Sevilla (en 1918 y 1925), respectivamente (Fig. 21). Comparten características con los calibres siguientes: $7 \times 57 \mathrm{~mm}$ de fabricación mexicana (FNC de Cuernavaca). Por su parte, el marcaje es "P S 1925" y "P S 1918". Además hay que señalar que la vaina $n^{\circ} 12$ sufre una reutilización como un posible punzón.

De estos dos ejemplos de vainas, la $n^{\circ} 12$ tiene sus paralelos en las posiciones franquistas en el Frente de Guadalajara, dentro del Castillo de Abánades (Ruibal, 2010). $Y$ otras dos vainas, la $n^{\circ} 13$ y la $n^{\circ} 14$ encontradas en la U.E 105, proceden de Austria, de la fábrica Hirtenberger Patronen und Zundhüntchenfabrik, de Hirtenberg (Fig. 22). Presentan los siguientes calibres: 7
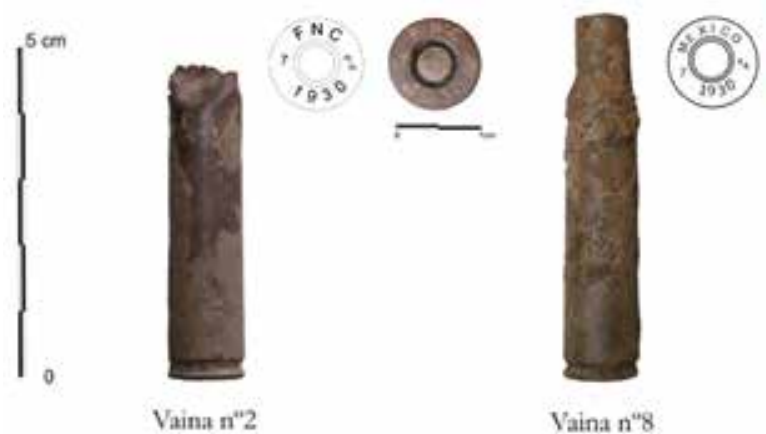

Fig. 20. Vainas procedentes de México. / Pods from Mexico.
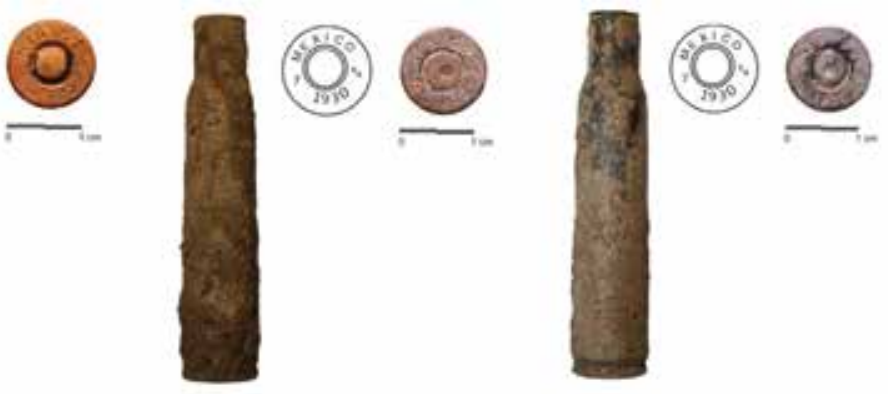

Vaina $n^{\circ 9}$

Vaina $n^{\circ} 10$

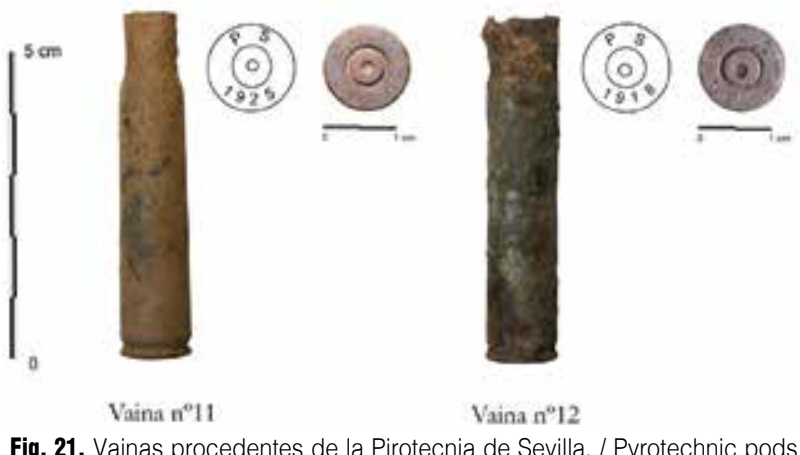

Fig. 21. Vainas procedentes de la Pirotecnia de Sevilla. / Pyrotechnic pods from Seville.

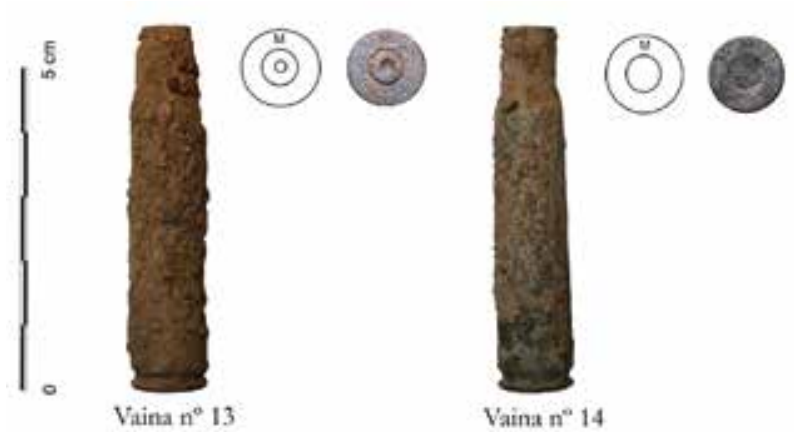

Fig. 22. Vainas procedentes de Austria. / Pods from Austria. 
x 57mm; 7x57/Mod.1893; 7mm/Mauser español; 7mm/ Mauser mexicano; 7×56.75/Mauser brasileño. El tipo de cartucho es ordinario, fabricado en latón al igual que la bala y su marcaje es "M". Hay desacuerdos sobre el origen real de este marcaje, aunque la calidad con que está hecho nos decanta hacia la posibilidad de que sea de fabricación austriaca. La marca "M" del culotte pertenece a la fábrica austriaca Hirtenberg, cartuchos destinados a México y desviados a la Republica (Mortera Perez, s.f.). Su origen republicano esta fuera de dudas.

Estas vainas de procedencia austriaca, han sido documentadas en el yacimiento de La Sendilla en Ciempozuelos (Madrid) (Penedo et al., 2008), relacionadas con la Batalla del Jarama. Aparecen adscritas En el pozo de tirador al ejército republicano en la Batalla de Madrid las halladas en el refugio de Torrejón Velasco (López Fraile, et al., 2008) y en las posiciones franquistas en el Frente de Guadalajara, en el Castillo de Abánades (Ruibal, 2010).

En cuanto a los ejemplares italianos, contamos con un solo ejemplar (Fig. 23), y se trata de la vaina $n^{\circ} 1$ (U.E 101), fabricada en la Pirotechnica de Bolonia en 1935, con los siguientes calibres: 6,5 × 52/M.1891; Mannlicher - Carcano. Su cartucho es de tipo ordinario, fabricado en latón y bala es niquelada. El marcaje es "T.M.B-35".

Y por último, se ha localizado un ejemplar procedente de la U.R.S.S (Fig. 24), la vaina $n^{\circ} 3$-U.E 102-, fabricada en Luganski Patronyi Zavod de Lugansk, en el año 1925; un casquillo de Mannlicher - Carcano de 6’5 x 52mm con un marcaje "л (L cirílica) 1-25".

A las vainas ya tratadas, tenemos que sumar la recuperación de cinco proyectiles o balas, y un peine de "lámina" o "de muelle". Los proyectiles se pueden catalogar según el calibre (grosor máximo, en milímetros), la forma (forma del cuerpo y de la ojiva), la formación (con

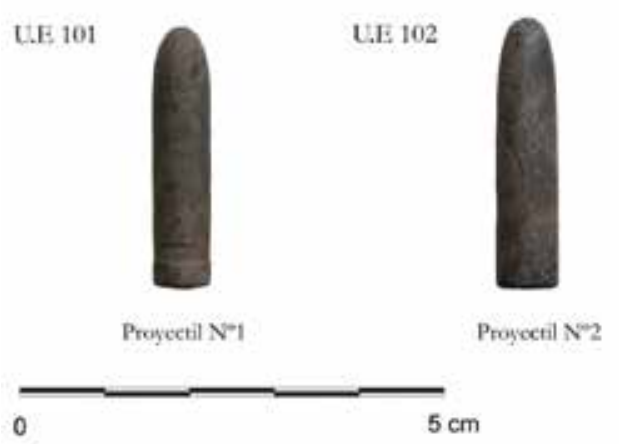

tres tipos básicos: el macizo, el blindado y el semiblindado), la presencia o ausencia de estrías (estriado o rayado formando un suave giro), estado de conservación, etc. (Martín Velasco, 2008). Estos proyectiles $n^{\circ} 1, n^{\circ} 2, n^{\circ} 4$ y n`5 (Fig. 25): tienen $6 \mathrm{~mm}$ de calibre, son de forma cilíndrica hemisférica, blindados de formación y cuentan con unas ranuras para fijar la boca de la vaina. Y el proyectil n 3 tiene el mismo calibre y forma que los anteriores pero cuenta con núcleo de plomo y está envuelto en acero.

Respecto al vestigio de resto de peine recuperado en la U.E 105, tenemos que señalar que se trata de una pieza de metal, con dos bordes internos por los que se introduce la ranura del cartucho teniendo una capacidad de cinco cartuchos (Fig. 26). Tiene una longitud de

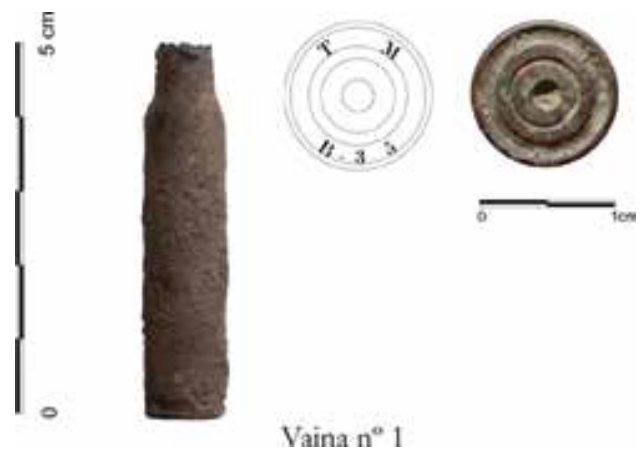

Fig. 23. Vaina procedente de Italia. / Pods from Italy.

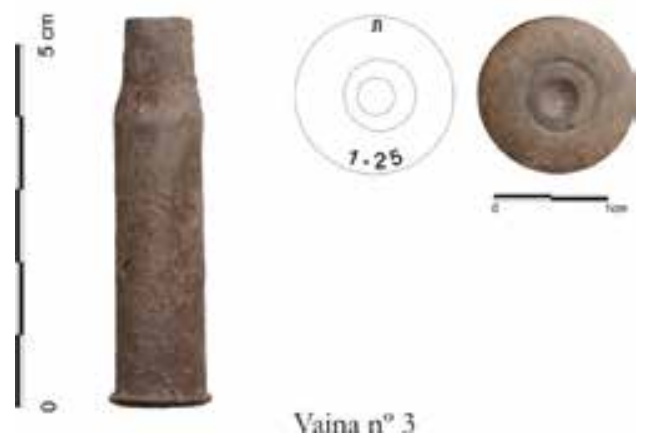

Fig. 24. Vaina procedente de la antigua U.R.S.S. / Pods from the former U.S.S.R
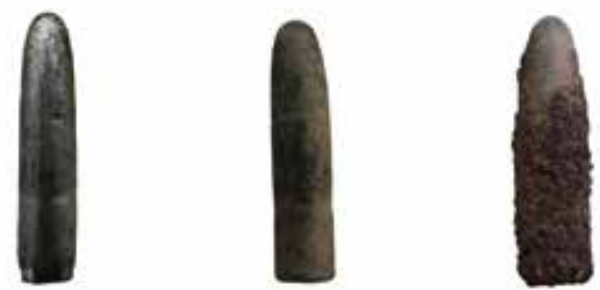

Proycectil N"3

Proyectil $\mathrm{N}^{-4}$

Proyectil No5

Fig. 25. Proyectiles recuperados. / Projectiles recovered.
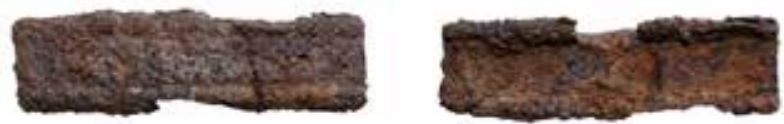

0 $5 \mathrm{~cm}$

Fig. 26. Peine de muelle de calibre $7 \times 57$, para Máuser. / Spring comb $7 \times 57$ caliber for Mauser. 


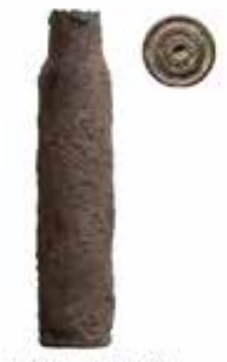

UE.101. Vaina $\mathrm{N}^{\mathrm{N}} 1$
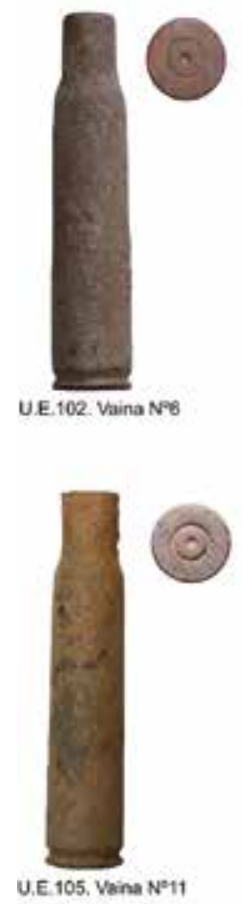
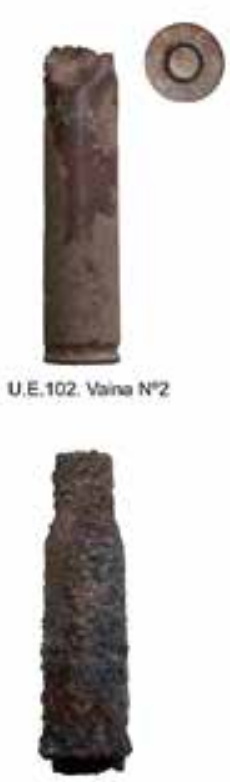

U.E.102. Vaina N"7

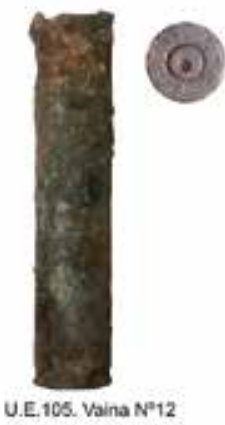

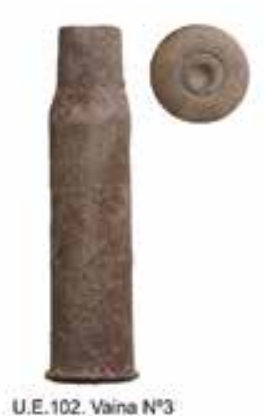

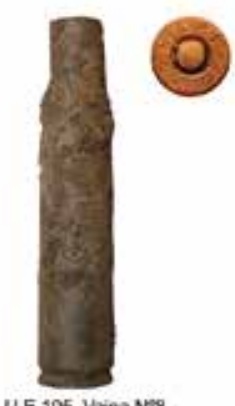

U.E. 105. Vaina NF

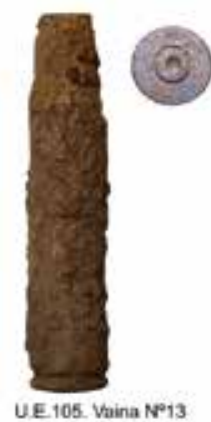

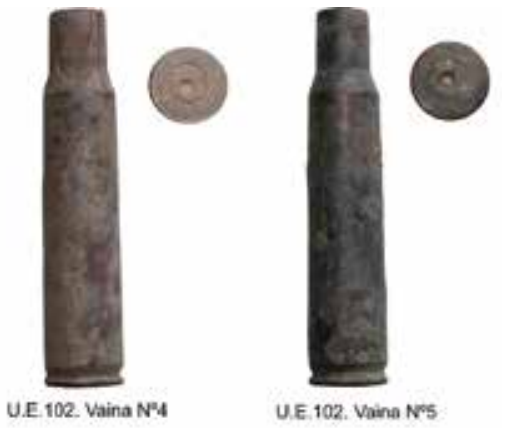

U.E. 102. Vaina $\mathrm{N}^{2} 4$

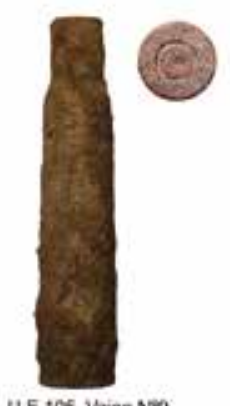

U.E.105. Vina Ne9
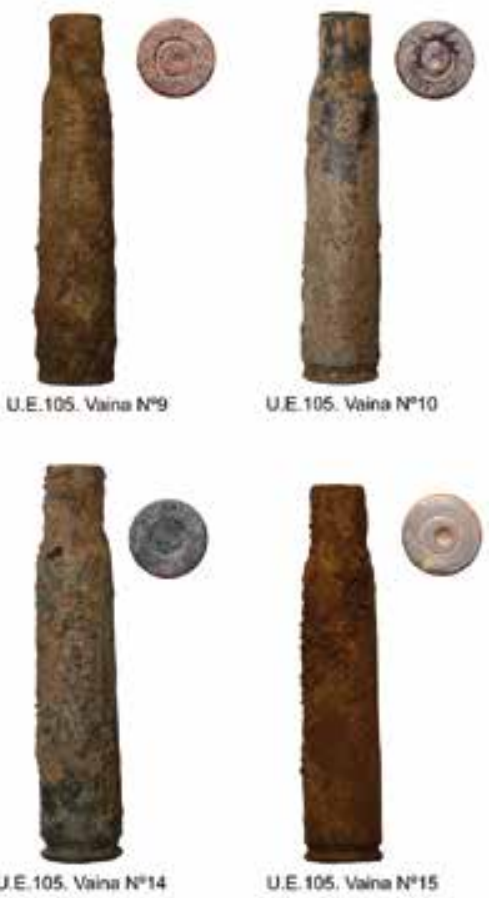

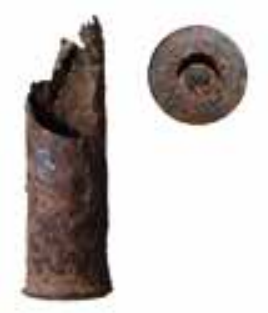

U.E 203. Vaina No16
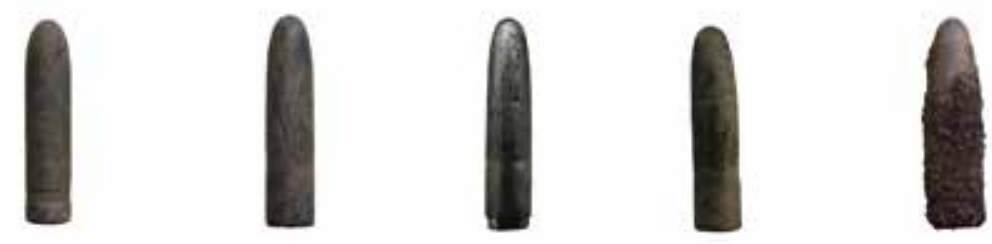

U.E 101. Proyect No'

U.E 102. Proyectil N/2

UE 105. Proyecel Nrs

UE 105. Proyecti No4

UE 108. Proyectii Nef
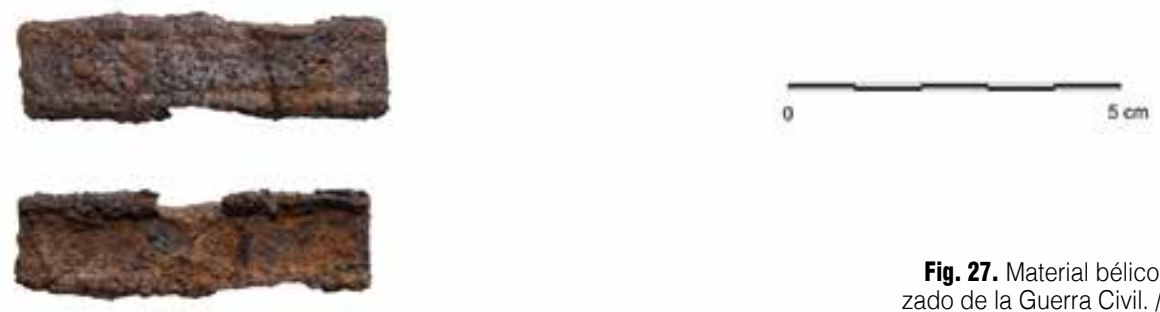

UE 105 Pane sai imira

Fig. 27. Material bélico localizado de la Guerra Civil. / Materiel located from the Civil War. 
$60.1 \mathrm{~mm}$, una anchura de $14.6 \mathrm{~mm}$, una altura de 5.6 $\mathrm{mm}$ y cuenta con una ligera curvatura de unos $0.5 \mathrm{~mm}$ en el centro. Este peine es para fusil Máuser de calibre $7 \times 57$, arma muy común durante la Guerra Civil Española. Se trata de los fusiles reglamentarios al servicio en España desde finales del siglo XIX.

Este modelo de peine se ha detectado en las excavaciones del Monte Bernorio en Palencia, importante yacimiento de la Edad de Hierro en el norte de la Península Ibérica que fue escenario de batalla durante la Guerra Civil (Torres-Martínez y Domínguez-Solera, 2008). Además también se halló en la excavación de El Cigarral 3 en una antigua construcción de los ss. XVI/ XVII, reaprovechada en el Frente Sur del Tajo (Barroso Cabrera et al., 2011).

\subsection{Análisis Micro-espacial}

Durante el transcurso de la excavación arqueológica, empleamos un registro exhaustivo y rigoroso de los datos proporcionados por la misma, mediante un análisis micro espacial (Fig. 28). Así evaluamos una dispersión singular con respecto a los restos arqueológicos vinculados a la contienda bélica que aquí tratamos. Este estudio permite una interpretación amplia apoyada en la interacción de los elementos en un contexto global del conjunto artefactual (Fig. 29)

Los primeros elementos que localizamos, son una vaina procedente de Italia (adscrito al ejército sublevado y posiblemente a los fechas azules) y un proyectil, registrado en la U.E 101 (unidad de derrumbe). La siguiente unidad con material de este periodo es la U.E 102 (unidad de relleno) en la que localizamos un proyectil y un total de seis vainas relacionadas con la munición del ejercito republicano.

La última unidad, U.E. 105, corresponde a la fosa de inhumación. En esta localizamos los elementos propios del soldado exhumado (ver epígrafe 4, descripción de la inhumación). Se registra el mayor número de artefactos, formados por ocho vainas, tres proyectiles y restos de un peine de cargador. Las vainas proceden tres de México, dos de Austria, dos de Sevilla y una
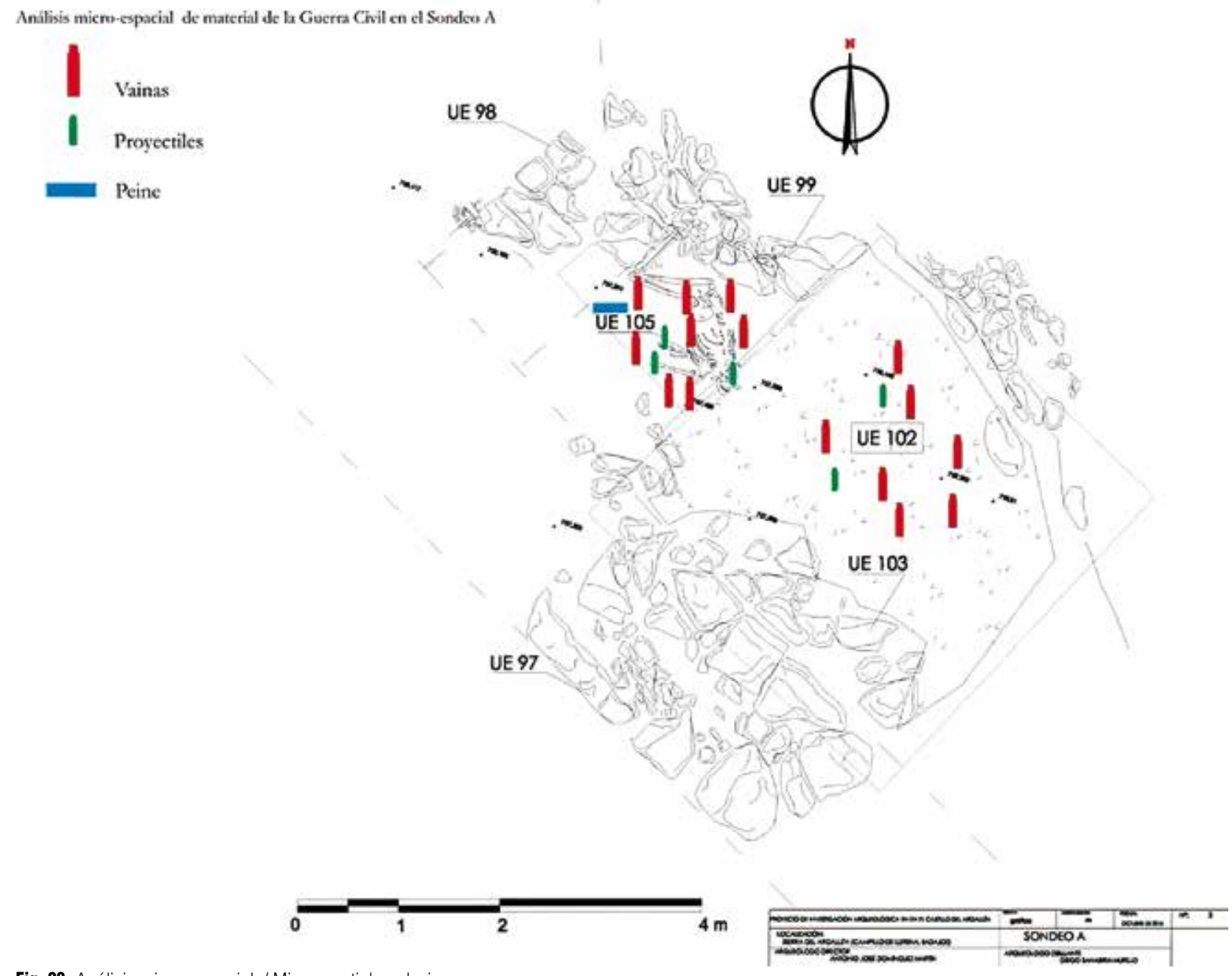

Fig. 28. Análisis micro-espacial. / Micro-spatial analysis. 

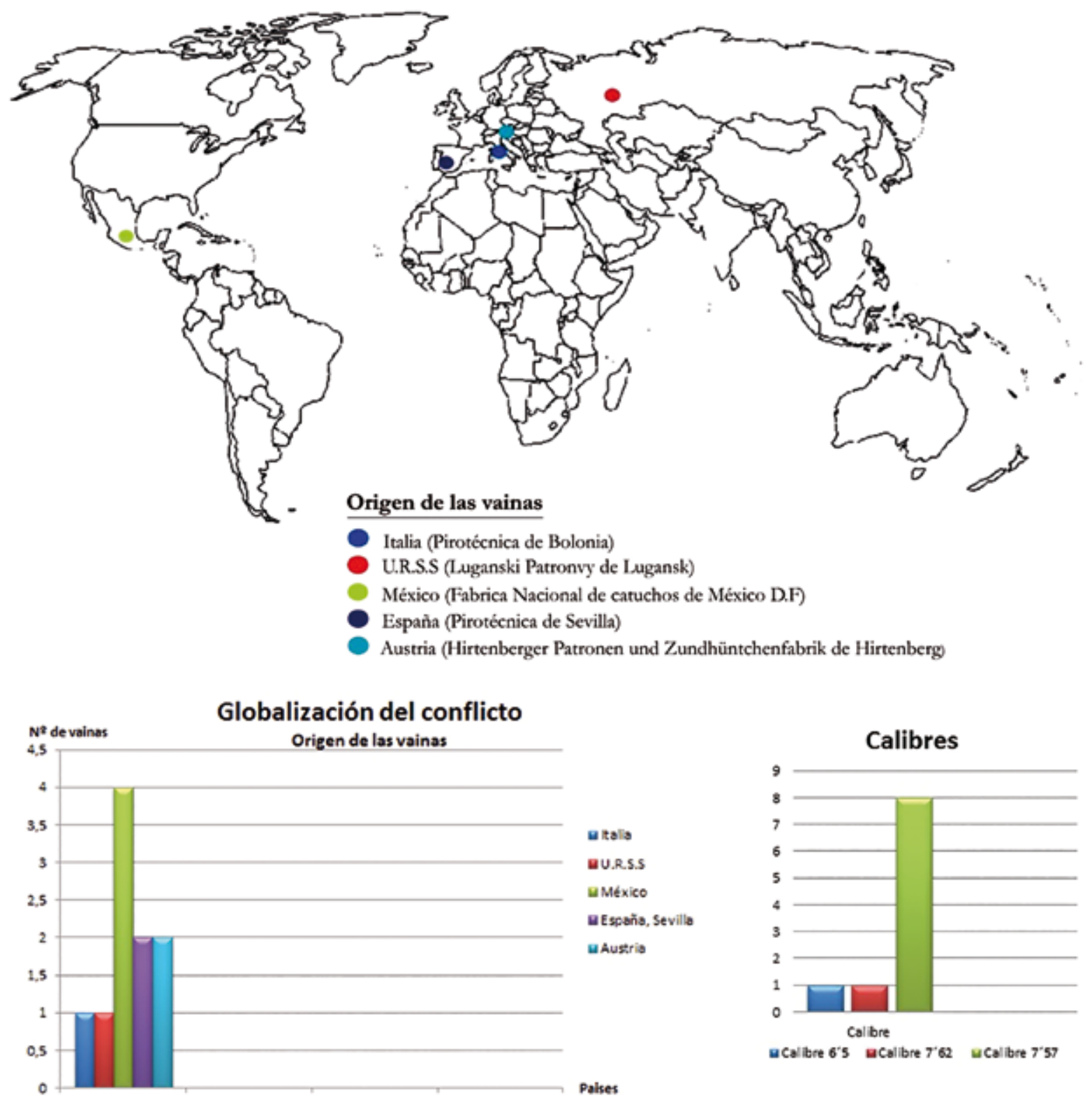

Fig. 29. Globalización del conflicto, origen de las vainas y calibres. / Globalization of the conflict, the origin of the pods and gauges.

sin identificar. Todas estos elementos están también relacionados con el ejército republicano y apunta a que con toda probabilidad el soldado estaba armado con un Máuser de calibre 7×57, calibre de todas las vainas, aquí localizada.

\section{DESCRIPCIÓN DE LA INHUMACIÓN}

La inhumación comprende un enterramiento individual y primario, cuya descomposición tuvo lugar en espacio colmatado (Ubelaker, 1984; Duday, 1997). Refleja un soterramiento improvisado, ya que la potencia no superaba los $22 \mathrm{~cm}$ y no se determinaron límites que definiesen una fosa excavada en tierra. El individuo se encontraba en conexión anatómica y en posición de decúbito prono, con orientación N-S (Fig. 30). El esqueleto craneal y la extremidad superior derecha exponen efectos postdeposicionales (Fig. 31), pero por la posición del cadáver se infiere que quedó en el mismo sitio y en la misma postura en la que falleció (Haglund y Sorg, 2002).Del esqueleto craneal apenas se recuperaron algunos fragmentos de la calota, mandíbula o maxilar. Sin embargo el esqueleto postcraneal se conservaba casi completo, la extremidad superior izquierda se encontraba dispuesta bajo el tórax, exponiendo su cara medial, y la extremidad superior derecha extendida en ángulo recto con el eje axial del esqueleto. Las extremidades inferiores se encontraban flexionadas a nivel de la rodilla, adquiriendo el cuerpo una posición casi fetal. 

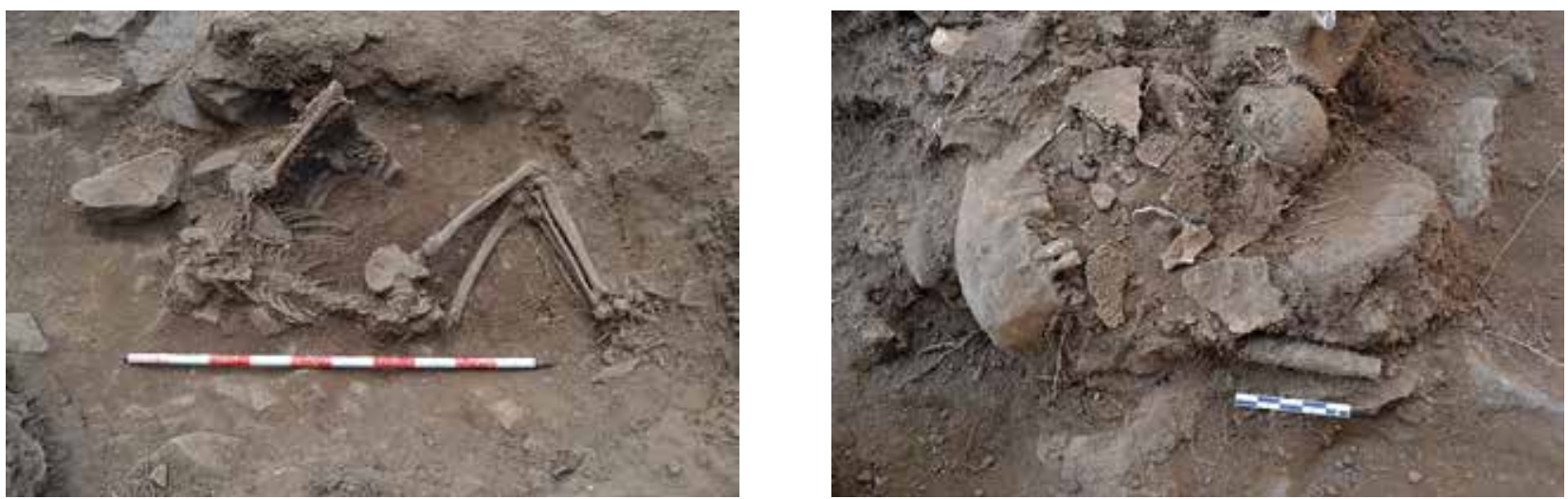

Fig. 30, 31. Enterramiento y restos del soldado localizado en la Sierra de Argallén. / Burial and remains of the soldier located in the Sierra de Argallén.

En función de los materiales asociados a los restos, que se recuperaron durante la exhumación, podemos inferir su atuendo. En la región torácica y abdominal fueron recuperados elementos como fragmentos de tela y cinco botones de nácar, probablemente de una camisa. También en esta región anatómica apareció un corchete metálico y fragmentos de cuero, que quizás formasen parte de algún correaje. Por otro lado, asociados a la pelvis se recuperaron fragmentos de cremallera y un botón metálico, que compondrían el pantalón. En la misma región, además aparecieron otros dos botones de nácar de la ropa interior, fragmentos de cuero y goma, y ocho corchetes.metálicos, aparecieron asociados a las extremidades inferiores hasta el tercio medio de la diáfisis de la tibia, lo que podría corresponder con unas polainas, ya que no se recuperaron suelas del calzado (Fig. 32 y 33). Adyacente al cuerpo se recuperó gran concentración de municion tipo Mauser $7 \mathrm{~m} / \mathrm{m}$ México 1930, un peine-cargador, una anilla de granada y un gran fragmento de metralla. Por la orientación de los restos, así como por los casquillos localizados, lo más probable es que este soldado estuviera cubriendo la primera línea republicana fortificada.

\subsection{Resultados del estudio antropológico forense}

Tanto en la actuación en campo como en su posterior análisis en laboratorio, se tuvo en cuenta el protocolo de actuación en exhumaciones de víctimas de la Guerra Civil y la Dictadura (BOE 232, 27-09-2011) y las primeras recomendaciones elaboradas en la materia por Etxeberría (2004). Los restos óseos junto al material asociado, fueron trasladados a la Facultad de Medicina de la Universidad Complutense de Madrid para su estudio Antropológico Forense. La metodología aplicada en laboratorio fue seleccionada en función de los elementos óseos recuperados y su estado de conservación, siguiendo los protocolos clásicos en antropología forense.

El individuo exhumado corresponde a un varón con una edad de muerte entorno a los 25-30 años y una estatura de 1,70 $6,90 \mathrm{~cm}$ (Krenzer, 2006; Buikstra y Ubelaker, 1994; Krogman e Iscan, 1986). Se distinguieron marcadores de estrés ocupacional como la fuerte inserción del deltoides en el humero derecho. Entre los marcadores patológicos localizados destacan procesos degenerativos como nódulos de Schmörl en tres vertebras torácicas, o patologías bucodentales como caries o abscesos (Ortner, 2003; Aufderheide y Rodriguez-Martin, 1998; Hillson, 2000).

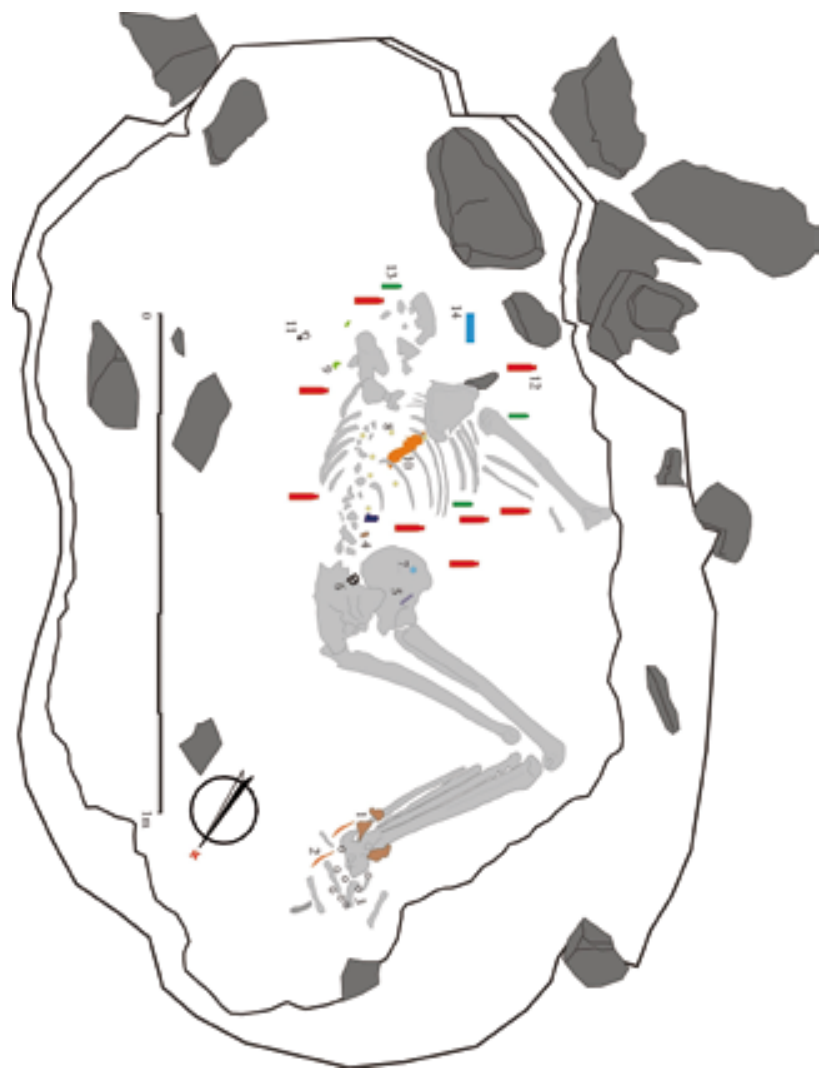

Fig. 32. Planimetría de la inhumación. / Planimetry of burial. 


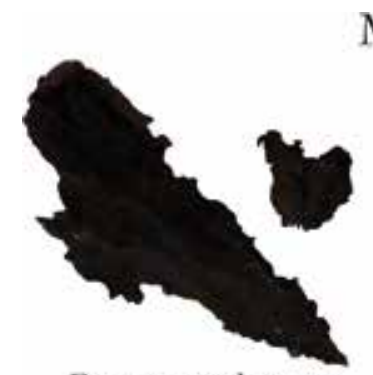

Fragmentos de cuero

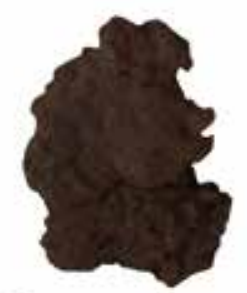

Fragmento de cuero

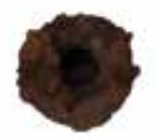

Botón metálico

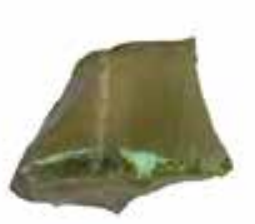

Fragmentos de vidrio
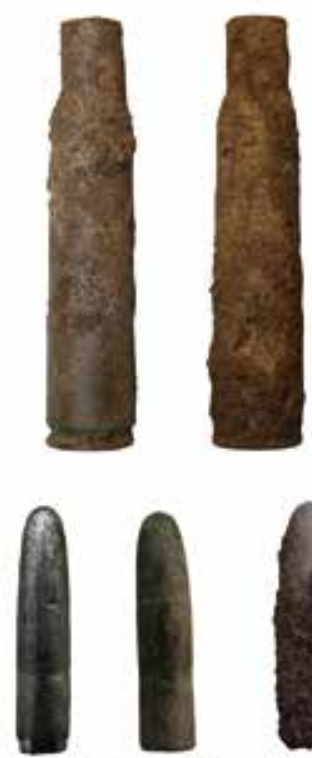

Proyectiles

\section{MATERIAL ASOCIADO AL INDIVIDUO}
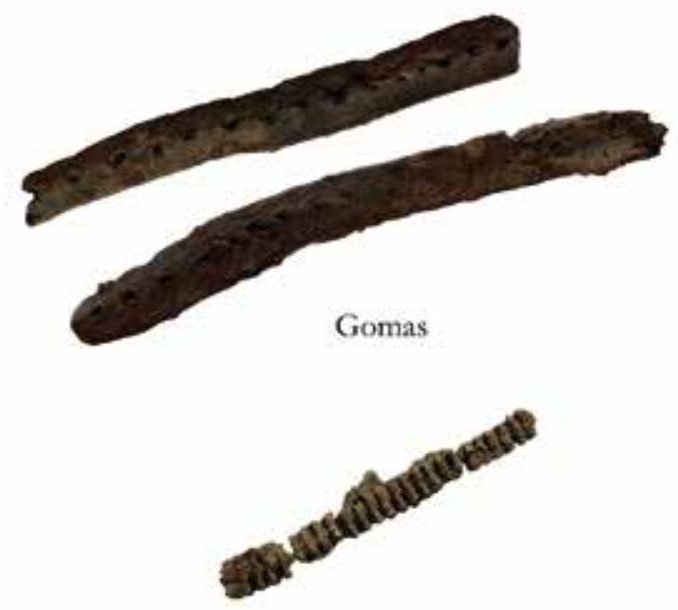

Cremallera metálica

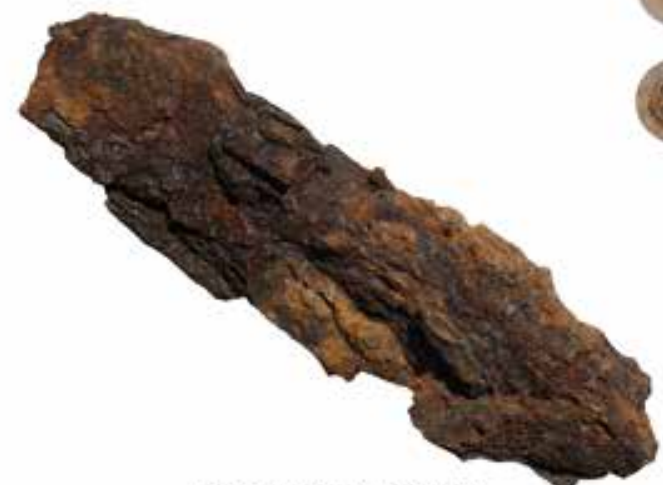

Fragmento de metralla
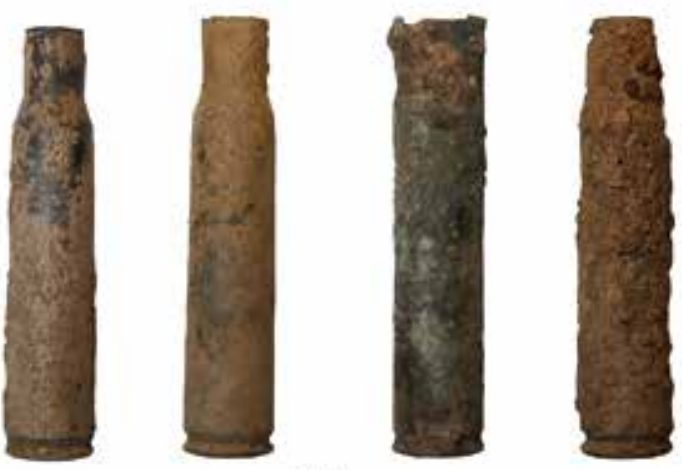

Vainas

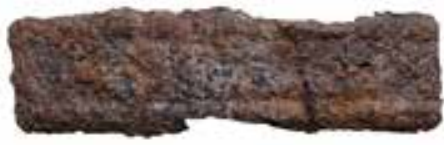

Peine-cargador
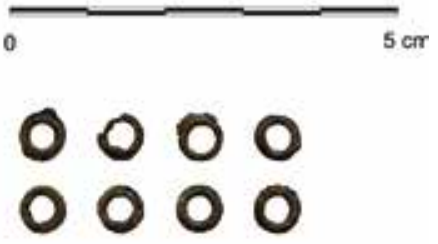

Corchetes metálicos

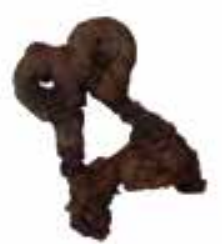

Enganche o cierre metálico
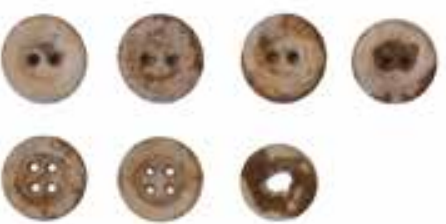

Botones de nácar

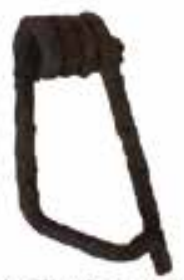

Anilla de granada
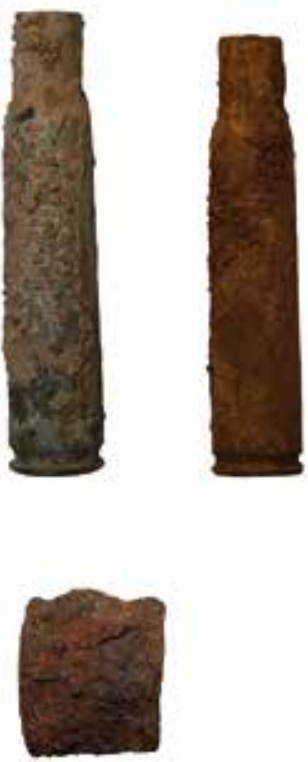

Fragmento de metal

Fig. 33. Materiales asociados al individuo. / Associated materials to the individual. 
En el estudio del traumatismo perimortem se localizaron marcadores característicos de la respuesta plástica del hueso fresco, concretamente en el humero izquierdo, que presenta una fractura conminuta en el tercio superior de la diáfisis. Posiblemente dicho traumatismo se relacione con el paso de proyectil de arma de fuego o por impacto directo, ya que también se ha observado en la cabeza humeral un orificio irregular del que nacen amplias líneas radiales, además de exponer tinción verdosa debido al contacto directo con metales (Fig. 34). Por otro lado en los fragmentos de maxilar recuperados, se han observado líneas de fractura, posiblemente secundarias a un traumatismo perimortem inicial (Wedel y Galloway, 2014; Kimmerle y Baraybar, 2001).

No se dispone de información o documentación antemortem, u objetos asociados que permita el proceso de identificación del individuo. Por otro lado, para posibles cotejos genéticos en un futuro, se ha tomado una muestra ósea que será custodiada en la Escuela de Medicina Legal de Madrid hasta la realización de dichos análisis.

\subsection{Otros caídos en combate}

Existen enterramientos similares localizados en distintos frentes de la Guerra Civil Española. Las inhumaciones de combatientes del Ejército Popular de la República suelen asociarse a estructuras como trincheras y la mayoría de ellas comprenden enterramientos improvisados. En los individuos exhumados se estiman perfiles biológicos similares y en todos ellos se documentan traumatismos perimortem, asociados al paso de proyectiles de arma de fuego o impactos por proyectil de artillería. Los materiales asociados también presentan similitud, recuperándose elementos propios de la vestimenta y el calzado, enseres personales y materiales propios de contextos bélicos como gran cantidad de munición, peines de cargador, granadas o fragmentos de proyectil de artillería. Se han logrado algunas identificaciones gracias a chapas de identificación, donde

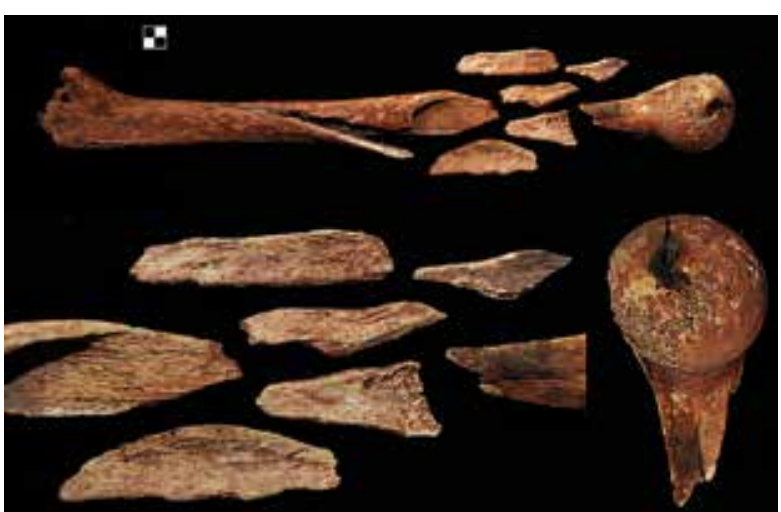

Fig. 34. Fractura en conminuta en el tercio superior de la diáfisis del humero izquierdo. / Comminuted fracture in the upper third of the diaphysis of the left humerus. se grababa el número de registro como combatiente, además de la mención al batallón (Herrasti et al., 2014).

En la ciudad de Madrid se han localizado inhumaciones de combatientes desde los años 80, debido por lo general a la realización de obras que dejan al descubierto los restos (González-Ruibal, 2016). Entre los casos documentados destacan los restos de tres brigadistas exhumados en la Casa de Campo, lugar de importantes batallas en los primeros meses del conflicto (Reverte, 1984). Se trata de tres individuos encuadrados en la brigada Kléber que luchó en ese sector del parque en noviembre de 1936, antes del asalto franquista a la Ciudad Universitaria. Los individuos de edades comprendidas entre los 25-35 años exponían traumatismos perimortem en el cráneo. Entre los materiales asociados se encontraban botones y varias cartuchos Mauser de 7,92mm de fabricación checa datados en 1936.

También se han localizado enterramientos similares asociados a la Batalla del Jarama, como las inhumaciones en la línea de trincheras que formaba parte de sistema defensivo de Ciempozuelos en 1937 (Penedo et al., 2009). Concretamente en el "Puesto 2" aparecieron los restos de dos soldados de edades comprendidas entre los 20-25 años, que exponían traumatismos asociados al impacto de proyectiles de arma de fuego. Los objetos asociados se corresponden con botones de nácar, cremalleras, peines de Mosin y Mauser o vainas de Mosin Nagant de 7,62mm.

En la Ofensiva del Norte fue localizada la inhumación de un combatiente durante la rehabilitación de trincheras en Lemoatz (Bizcaia) (Etxeberría y Herrasti, 2014). La muerte de este soldado se produjo durante los días 3 a 5 de junio de 1937, cuando tuvo lugar el contraataque de las tropas franquistas en su avance hacia el Cinturón de Hierro de Bilbao, y puede ser atribuida a una explosión por los fragmentos de metralla que se han localizado entorno al esqueleto. Entre los materiales asociados se recuperó un cinturón de cuero con hebilla metálica propia de los batallones del Eusko Gudarostea, dos cartucheras completas, una granada, dos maquinillas de afeitar, una pluma estilográfica y dos cucharas. El proceso de identificación fue posible gracias a la chapa identificativa que portaba en una pulsera de cadena.

En distintos enclaves del Frente de Levante (Olba y Abejuela en Teruel o El Toro en Castellón) también se han documentado enteramientos muy similares asociados a estructuras como trincheras o refugios (Fortuna et al., 2015: Mezquida, 2015; Iglesias et al., 2014). Estos combatientes, probablemente republicanos, participaron en diversas batallas libradas entre julio y septiembre de 1938. Se han exhumado un total de 9 soldados, con edades comprendidas entre los 15- 40 años, que presentan marcadores patológicos asociados a enfermedades infecciosas y metabólicas, además de multitud de traumatismos perimortem asociados al paso de proyectiles de arma de fuego, impacto de metralla o incisiones de arma blanca. Se recuperaron materiales asociados 
como restos de ropa y calzado, utensilios de comida o enseres personales como gafas o mecheros "zippo", además de abundante munición Mosin y Mauser.

También en trincheras de la batalla del Ebro se han localizado inhumaciones de soldados republicanos. Un ejemplo es el caso del soldado localizado en el interior de una trinchera durante las excavaciones de los Auts en Mequinenza (Aragón). Junto al cuerpo se recuperaron las cartucheras completas, una granada y la bayoneta de su fusil, además de correajes, hebillas o una insignia con la bandera catalana y debajo la inscripción "PER CATALUNYA" (Pérez, 2016). En Tarragona, también en el interior de una trinchera, fue localizado "Charlie" Ilamado así por aquello de que era un combatiente de la XV Brigada, la Lincoln. Se estimó una edad próxima a la cuarentena y una estatura en torno a 1,75 $\mathrm{cm}$. Presentaba traumatismos relacionados con el impacto de metralla, seguramente al explotarle una granada en la mano derecha. La inhumación se localizaba el mismo ángulo de zigzag que estaba defendiendo, y se preservaron gran cantidad de materiales asociados como textiles relacionados con la vestimenta, la bolsa de costado o el calzado, una navaja, o cepillo de dientes, además de munición empaquetada, dos granadas polacas etc. (González Ruibal, 2012).

Al finalizar la guerra, en abril de 1939, no se creó ninguna comisión encargada de recuperar sistemáticamente los cadáveres de los caídos. Las trincheras y otras estructuras como parapetos, nidos de ametralladora o refugios se utilizaron con mucha frecuencia como lugar de enterramiento tras finalizar los combates (González-Ruibal, 2016).

\section{APUNTES HISTÓRICOS SOBRE LA ACTIVI- DAD BÉLICA EN LA ZONA SUR DEL FRENTE EX- TREMEÑO}

El golpe de Estado de julio de 1936 partió en dos a Extremadura. Los sublevados se impusieron en casi toda la provincia de Cáceres mientras que en Badajoz el golpe no triunfó. Pero desde primeros de agosto el avance sangriento de las columnas insurgentes desde Andalucía por la Provincia pacense marcó la suerte de miles de extremeños. A principios de agosto Mérida y Badajoz cayeron en poder de los insurrectos que continuaron su ascenso hacia Madrid. Sólo la zona Nororiental de la Provincia pacense quedó en poder gubernamental.

En el mes de octubre de 1936 el Frente extremeño se fue asentando. En su zona Sur, que será el sector en el que nos centraremos, y en ese mismo mes, hubo importantes acciones bélicas que afirmaron finalmente dónde se situarían las líneas a fortificar. Así, el 1 de octubre de 1936 eran ocupados por los sublevados los pueblos de Campillo de Llerena y Retamal. Unos días después, el 7 de octubre de 1936, hubo un intento de avance por un fuerte contingente rebelde sobre Higuera de La Serena que fue rechazado por los republicanos con bastantes bajas, replegándose a sus posiciones primitivas. Cerca de Higuera, en el vecino Valle, se rectificó sin resistencia y de manera favorable a los republicanos la línea del sector de Valle de La Serena. El Frente en esta zona se estabilizó teniendo al río Guadámez como línea divisoria entre los citados pueblos de Retamal y Campillo, en zona rebelde, y los de Higuera y Valle de La Serena en la parte republicana (fig. 35).

El 7 de enero de 1937 los Comandantes de las localidades cercanas al Frente recibían las instrucciones de organización de la defensa por parte del Teniente Coronel Jefe de la Columna de Operaciones de Extremadura $^{3}$. Los Comandantes las remitirían a los Comités de Defensa de los pueblos, o a los Consejos Municipales si ya hubieran sido constituidos. Se incidía en primer lugar en cómo se debía de llevar a cabo la estructura defensiva del Frente, que como veremos en su descripción coincide en los aportes que ha llevado a cabo la arqueología en la zona que nos ocupa:

"...Se construirán trincheras, pozos de tirador, ect en la primera línea, protegiendolos con alambradas. Se efectuaran asi mismo los atrincheramientos necesarios a retaguardia de los primeros, enlazadas ambas líneas por caminos cubiertos; estos atrincheramientos no han de constituir una línea continua, pero los intervalos que queden entre sus distintos trozos han de poder ser batidos por las armas situadas en los flancos y retaguardia. Las avenidas, caminos, pasos obligados se obstaculizarán con fosos, alambradas, traveses de piedra, ect al mismo tiempo que han de quedar bajo el fuego de armas que las batan de frente y flanco. Se construirán también asentamientos para armas automáticas y abrigos contra aviación, para conseguir que el personal de servicio en las trincheras y sirvientes de la máquina estén a cubierto en sus puestos cualquiera que sea el fuego que reciban."

A mediados de mayo de 1937 el Ministerio de la Guerra ordenaba la eliminación de los sectores y subsectores de la Agrupación Sur del Tajo-Extremadura integrando sus tropas en una nueva unidad militar el VII Cuerpo de Ejército. En el Frente Extremeño el VII Cuerpo de Ejército estaría formado por la 36 División (Brigadas Mixtas 47, 62, 104 y 113) y la 37 División (Brigadas Mixtas 20, 63, 91 y 109) (Martínez Bande, 1979:128) (Hinojosa 2009: 128).

En abril de 1937 varios jefes militares republicanos plantearon una ofensiva contra Mérida, cuyo objetivo principal era aislar a Andalucía del resto de la España sublevada (/d., 2009: 119-121). Se trataba del más tarde conocido como "Plan P", que tenía su origen en

\footnotetext{
${ }^{3}$ Centro Documental de la Memoria Histórica. Político-Social de Extremadura. Carpeta 27. Expediente 33.
} 


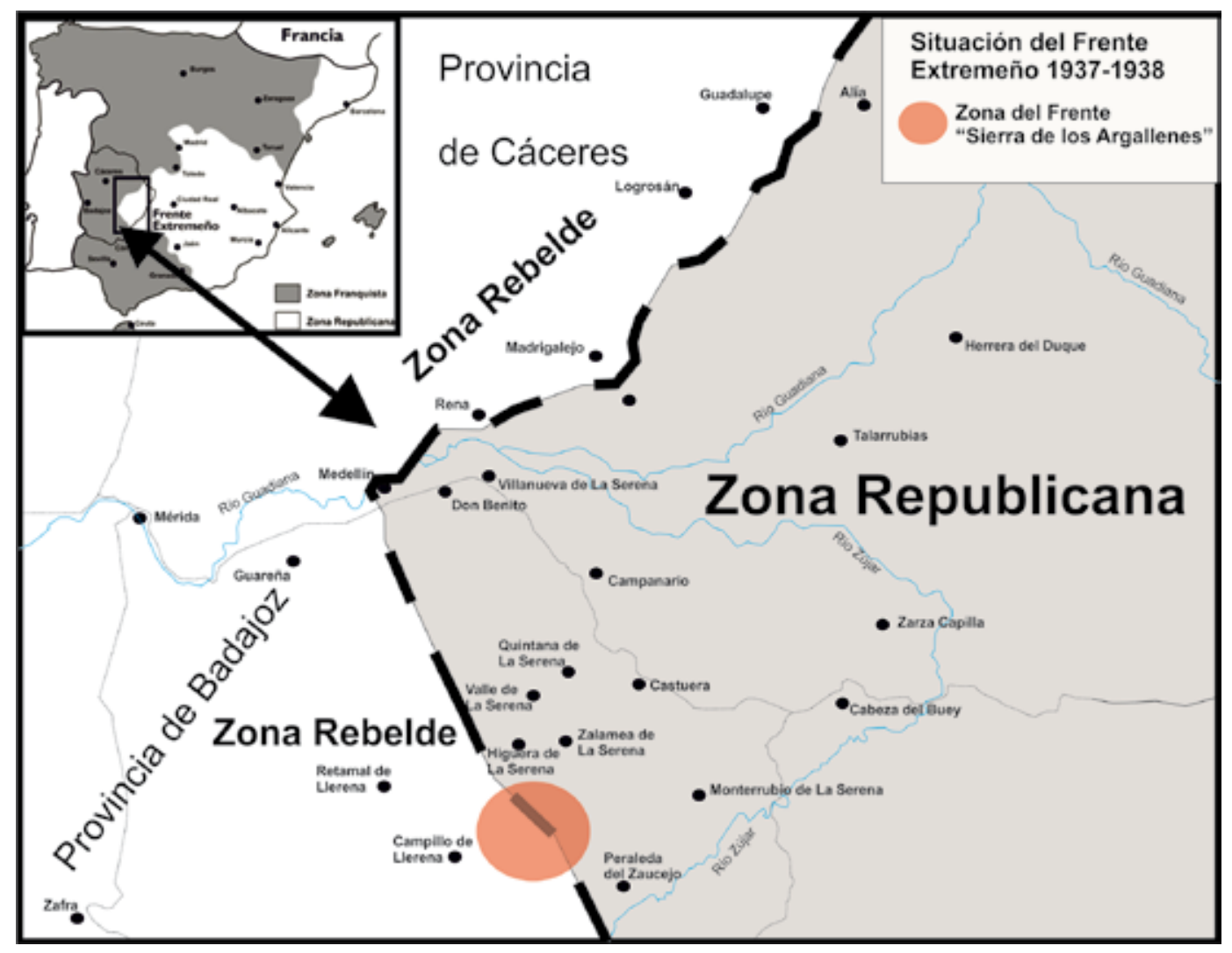

Fig. 35. Situación del Frente Extremeño 19371938 en la Sierra de los Argallanes. / Extremadura's Front location 1937-1938 in the Sierra de los Argallanes

los primeros meses de la guerra, y fue activado por el General Vicente Rojo tras la toma de Teruel en enero de 1938. Pero casi inmediatamente desestimado por el mismo General tras la contraofensiva franquista hacia dicha ciudad (Id:234). Esta ambiciosa operación ofensiva volvería a retomarse y ejecutarse a primeros de enero de 1939, y vertebrará buena parte del protagonismo del Frente extremeño en el escenario general de las operaciones de la Guerra Civil. El Frente extremeño se constituyó en un frente secundario, movilizado en función de las grandes batallas de la guerra. "Batallas" como la de Pozoblanco, la de Guadalajara o la ofensiva republicana sobre Teruel en diciembre determinaron la actividad en este Frente para el año 1937 y los inicios de 1938. Por supuesto esa dinámica de escenario bélico secundario continuó hasta el final de la Guerra.

\section{Año 1937: la primera “batalla” en la "Sierra de Argallén".}

El primer enfrentamiento en la zona del Frente extremeño fue iniciado por las fuerzas rebeldes, concretamente por la Primera Brigada Mixta Legionaria "Flechas Azules"5, que contaba con personal y material de guerra italiano. El día 12 de junio el ataque resultó muy efectivo para los rebeldes, previa preparación artillera y de presencia de aviones, ya que ocuparon "Sierra Lázaro", "Castillo Canalón" y las estribaciones de "Sierra de Ávila" y "Sierra de Argallén" (Fig.36)

Los soldados republicanos, pertenecientes al batallón 436 de la 109 Brigada (/d., 2009:142), se vieron sorprendidos y huyeron hacia el "Puerto de Higuera" por la carretera de Castuera. El resultado de la operación para las fuerzas rebeldes fue de cinco muertos y treinta heridos. Mientras que el número de prisioneros republicanos fue de veintinueve. La aplastante victoria y la falta de resistencia republicana elevarían la moral de los atacantes ya que propusieron a sus mandos superiores la posibilidad de avanzar incluso hasta Castuera. Pero pese a la falta de efectivos republicanos en la zona, detectada por los mandos rebeldes, al día siguiente por la tarde se produjo un intento de contraataque republicano. Según la información del ejército franquista la contraofensiva no prosperó por la llegada de su aviación. No obstante hacen constar en sus filas las bajas de un oficial muerto y dos soldados heridos. Aunque las bajas por deserción de las trincheras republicanas fueron cuantiosas. El parte habla de una sección "con 2 oficiales, un sargento, 5 cabos y 32 soldados" que se han pasado a nuestras filas, así como un teniente, nueve milicianos,

${ }^{5}$ AGMAV. Ejército del Sur. Operaciones. Parte de novedades de la 1a Brigada Mixta Legionaria. Junio de 1937. Armario 18/ Legajo 19/ Carpeta 110. 


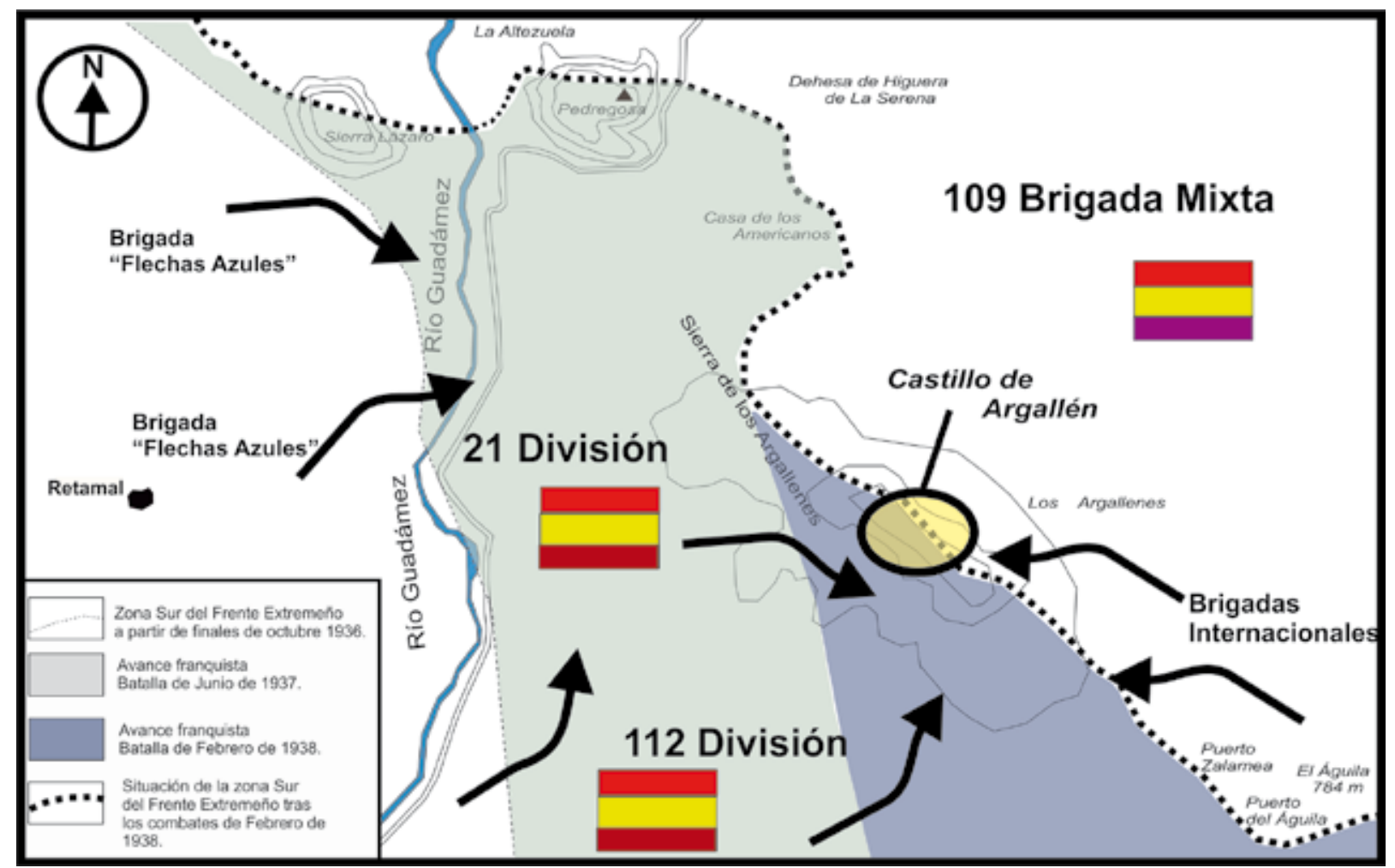

Fig. 36. Situaciones del Frente en la zona de Argallén y sus batallas (1937 y 1938). / Front locations in Argallén area and its battles (1937 and 1938).

de ellos dos heridos". Apuntaban que la Brigada republicana que realizó el contraataque fue la que participó en el asalto al Santuario de la Cabeza (Jaén), por tanto la 16 Brigada. Fue uno de los refuerzos llegados a esta zona del Frente junto con la $63^{\mathrm{a}}$ Brigada y otro batallón de la 109a, el 434 (Id., 2009:142). Las bajas republicanas se concentraron en el segundo batallón de la 109a con cuatro muertos, dieciséis heridos y cuarenta desaparecidos. Entre los oficiales republicanos fallecidos estaba el Mayor Luis Pedreño, jefe de la 109a Brigada ${ }^{6}$.

Al día siguiente los contraataques republicanos continuaron, siendo rechazados por las fuerzas rebeldes. El resultado de estas operaciones era descrito el 22 de marzo de 1937 por el Boletín de Información del VII Cuerpo de Ejército republicano:

"Frente al sector ocupado por la Brigada 63 (republicanos), existe una compañía (Brigada Mixta Legionaria Flechas Azules) con nueve ametralladoras y seis fusiles ametralladores. Dicha Compañía es la que ha intentado ocupar el Castillo de Argallén y rechazado por nuestras fuerzas. A la retaguardia de esta compañía quedaban las restantes hasta completar el Batallón. Otro Batallón está en Campillo y otro en el puente que hay sobre el
Guadamez donde la carretera de Higuera a Campillo se divide en otras tres entre Campillo y Retamal"".

\section{AÑo 1938: EL INICIO DEL FIN DE LA RESISTENCIA REPU- blicana en La SERENA.}

El año 1938 se inició con una fuerte ofensiva del ejército rebelde en la unión de los dos cuerpos de ejército que formaban el Frente de Extremadura, concretamente en el sector defendido por la $103^{a}$ B.M. de la $38^{a}$ División (Frente cordobés), en el límite más al sur del Frente Extremeño, junto a Peraleda del Zaucejo ( /d, 2009:233). A continuación la contraofensiva diseñada por el coronel Ricardo Burillo (Hinojosa ld::139) para recuperar las posiciones perdidas fue abortada por orden del General Jefe del Estado Mayor Central, Vicente Rojo. Al parecer se quería poner en marcha el ya aludido "Plan P", y para el 30 de enero la decisión parecía estar ya tomada (/d., 2009: 233). Pero todo se iría al traste con la gran ofensiva rebelde de febrero de 1938 en Teruel.

A su vez el ejército rebelde venía proponiendo en sus informes la ocupación total del territorio republicano

\footnotetext{
${ }^{6}$ En la red existe un trabajo realizado por José Vázquez Pedreño, nieto del Mayor Luis Pedreño, donde ofrece información sobre la 109 Brigada Mixta y algunos aspectos de la batalla de junio de 1937.

7 AGMAV. Documentación Roja. Séptimo Cuerpo de Ejército. Resumen semanal del Boletín de Información de la 37 División. (Junio de 1937). A. 64/C. 5/L.950.
} 
pacense. Estos propósitos empezaron a materializarse con el estudio para el día 6 de febrero de la ocupación del "Puerto de Zalamea". Dos días después se redactaban las órdenes de operaciones que tenían como objetivos el macizo de "Los Pollos" y la ocupación de la "Sierra Argallén". Esta operación supondría "la unión de ese macizo con nuestras posiciones de la casa de los Americanos"8. El mando conjunto lo tendría el coronel Solans ${ }^{9}$. Y aunque Martínez Bande se equivoca al fechar la progresión de las unidades rebeldes sobre el terreno, el diario de operaciones de la 21 División sintetiza con precisión cómo cumplieron los objetivos y su cronología:

"El día 4 se efectuó la operación para ocupar María Mingo, Cerro Mirón y Sierra Gamara en el frente de Campillo, quedando dicho día logrados los objetivos. El día 11, se ocuparon las posiciones de Los Pollos, Cabeza y Cencerrillo del Sector de Campillo. El 12, Puerto de Zalamea, Sierra de Argallén y Castillo del mismo nombre en el Sector anterior. "10

Y más concretamente el diario de operaciones de la otra División que participó en la ofensiva, la 112, describe con mayor exactitud el momento en el que el "Castillo de Argallén" fue ocupado por los soldados franquistas:

"A las 19 horas 30 minutos de dicho día 12 se inició una preparación artillera, en la que intervinieron los cuatro Grupos de que se disponían, sobre el objetivo $n^{\circ} 8$ que fue asaltado a continuación por la $2^{a}$ media Brigada de la $2^{a}$ Brigada, ocupándose en su mayor parte y sosteniendo fuerte tiroteo con el enemigo que guarnecía el resto de dicho objetivo, hasta las 16 horas 30 minutos en que tras un rápido fuego de artillería fue ocupado la totalidad del objetivo 8 y 7 en decidido avance que hizo huir al enemigo del resto de la línea y del castillo de Argallén que fue ocupado ya de noche."11

En este momento se pudo producir la muerte del soldado descubierto, defendiendo su posición. A continuación los rebeldes amortizarían la línea fortificada recién tomada situando la nueva trinchera a espaldas de la republicana y apuntando por tanto al Noroeste. Tras este exitoso avance rebelde sí hubo contraofensiva republicana aunque su verdadero fin fuera una operación "de diversión" para aliviar la presión que en esos momentos ejercía el ejército rebelde en Teruel (/d., 2009:235). Por tanto la ofensiva tenía origen en el alto mando militar republicano. Esto explicaría que la composición de las fuerzas republicanas no estuviera formada únicamente con las tropas del Frente extremeño. Así a la operación se sumaron efectivos de las Brigadas $63^{\mathrm{a}}$ y $109^{\mathrm{a}}$, y del Ejército de Andalucía, la Brigada $106^{\mathrm{a}}$, a las que se unieron las fuerzas pertenecientes a la $45^{a}$ División, concretamente las Brigadas Internacionales XII (italianos) y XIII (eslavos). Su participación puede nombrarse como la mayor intervención de voluntarios de las Brigadas Internacionales en el Frente Extremeño durante toda la guerra. Además se sumaría una compañía de coches blindados, una compañía del Batallón Autónomo $n^{\circ} 7$ del VII C.E., una sección de camiones y fuerza de artillería. Para la puesta en marcha de la contraofensiva el alemán Hans Khale, jefe que dirigía la operación, organizó todos los efectivos en tres agrupaciones.

Siguiendo el citado informe la idea que tenía el mando era infiltrarse en dos columnas: una entre las sierras del "Madroño" y "Sierra Quemada" y otra entre el camino de Campillo a Zalamea y la carretera de Sevilla. Esta última se dirigiría hacia la retaguardia franquista avanzando con la primera hacia el pueblo de Campillo de Llerena "en cuyo sector las dos columnas debían tomar contacto, dejando la limpieza de los focos de resistencia en las sierras al cuidado de los segundos escalones de las dos columnas"12.

El ataque se inició la noche del 15 al 16 de febrero sorprendiendo totalmente a los franquistas en sus posiciones. Debido al éxito del avance los republicanos reconquistaron las posiciones en las "Sierras del Águila" y de los "Argallenes", en el norte, y "Sierra Quemada" y del "Acebuche", en el Sur. Por la descripción del diario de operaciones de la 112 División conocemos cómo vivieron los rebeldes el ataque republicano:

"Habiendo sido atacado nuestro frente de la Sierra de los Argallanes por un enemigo numeroso compuesto por la Brigada "Garibaldi" (Internacional) y la 106 Brigada Mixta en primera línea, y otras dos Brigadas en reserva; habiendo sido roto nuestro frente por debilidad de la guarnición del puesto llamado del Cencerrillo, ocupado por el enemigo a primeras horas de la mañana del día 16 y habiéndose filtrado la Brigada "Garibaldi" (Internacional) y dos Batallones de la 106 Brigada Mixta por el puerto de Zalamea irrumpiendo en el llano comprendido entre la Sierra de Argallanes y la carretera de Campillo de Llerena a Peraleda del Zaucejo..."

\footnotetext{
8 AGMAV. ZN. Ejército del Sur. L. 22, C. 18 y 24.

${ }^{9}$ La "A" estaba formada por la I Brigada y la mitad de la II Brigada de la 112 División, un Regimiento de Caballería, dos secciones de Auto-ametralladoras-cañón, dos grupos de Artillería y cinco compañías de Ingenieros. La Agrupación "B" tenía un batallón de la 21 División y otro de la 22, un Regimiento de Caballería, una sección de auto-ametralladoras-cañón, y dos baterías. La Agrupación "C", de reserva, se componía de dos Batallones de Castilla y un Regimiento de Caballería. La Artillería de Acción de Conjunto tenía dos grupos.

${ }^{10}$ AGMAV. Documentación Nacional. Diario de operaciones. 21 División. A. 10/C. 22/ L. 452.

${ }^{11}$ AGMAV. Documentación Nacional. Diario de operaciones. Relatos de los combates librados por las fuerzas de esta Unidad. 112 División. A. 10/C. 7/ L. 457

${ }^{12}$ AGMAV. Documentación Roja (En adelante DR). Ejército de Extremadura. Estado Mayor. Operaciones. Informes sobre operaciones. Armario 62. Carpeta 10. Legajo 775.
} 
Pero la reacción de los efectivos más curtidos del ejército rebelde, moros y regulares, no tardaron en doblegar el ambicioso avance republicano ${ }^{13}$. El retroceso de la Columna B (XII Brigada) por agotamiento tras 15 horas de lucha se realizó sobre las sierras del "Águila" y la mayor parte de la de los "Argallenes". En esta retirada también se podría haber producido la muerte del soldado exhumado en el "Castillo de Argallén", ya que en su intento por consolidar sus posiciones podrían haber reutilizado las anteriores defensas republicanas. Aunque la documentación consultada no señala que se volviera a luchar entre las ruinas de la fortificación andalusí. Pero por otro lado la gran cantidad de vainas alrededor del soldado exhumado, que como hemos visto eran de producción extranjera, podría apuntar a las unidades Internacionales que participaron en la contraofensiva republicana.

En definitiva el resultado de la retirada fue la desbandada de la XII Brigada Internacional que arrastró a la XIII cuyos batallones "Palafox" y "Mickiewicz" fueron los que salieron peor parados (Engel, 2005: 34). La información del mando sobre las pérdidas republicanas da idea del desastre de la operación:

"En el transcurso de ésta operación hemos sufrido, según los partes avanzados de las Brigadas, un número de bajas que oscilan entre 600 y 650, de las cuales 400 son heridos y el resto, desaparecidos y muertos aproximadamente". ${ }^{14}$

Las bajas causadas al enemigo, las estimo en un total de 1.200 entre muertos, heridos y prisioneros capturados. Estos últimos en número aproximado de 145."

El informe al General Jefe del Estado Mayor Central resumía la contraofensiva de los días 16 y 17 de febrero de 1938 y criticaba principalmente tres aspectos. En primer lugar lo ambicioso de los objetivos finales de la operación, conquistar Campillo de Llerena y Granja de Torrehermosa. Y en segundo lugar la falta de coordinación entre las primeras líneas de infantería y de las reservas o la propia organización de las unidades republicanas: "Las agrupaciones se formaron irregularmente con batallones sueltos, desglosados de sus Mandos naturales de Brigada". La conclusión a la que se llegaba en el informe sobre la operación de contraataque era la siguiente:

“..la concepción de la operación aparece como deficiente; su preparación fue precipitada como aprecia el Mando de la 45 División, la coordinación de los Mandos subordinados e incluso del Mando Artillero tan defectuosa, debió ser fijada previamente por el Mando superior y la información que éste poseía del enemigo dejaba mucho que desear..."15

Pese a que a lo largo de los informes aludidos se apuntaba a la incompetencia de los mandos el único que fue sustituido fue el italiano Arturo Zanoni, nombrando al mayor de milicias Eloy Pardinas como su sustituto (/d., 2005: 32). La operación dejó prácticamente las posiciones de esta zona del Frente extremeño en su situación de partida. Y su configuración permaneció inalterada hasta las operaciones del llamado "cierre de la Bolsa de La Serena" entre junio y julio de 1938.

Las castigadas Brigadas XII y la XIII fueron alojadas en la vecina localidad de Zalamea de La Serena hasta el 10 de marzo de 1938 desde donde marcharon hacia la zona del Ebro. Los heridos serían atendidos en el Hospital Militar instalado en dicha localidad. Atrás quedaron cientos de desaparecidos, en fosas que no se identificaron, abandonados en la misma trinchera donde murieron como en el caso del soldado exhumado. Los familiares de estos "desaparecidos" aún hoy siguen buscándolos. Valga el ejemplo del sobrino de José Morote Telles que aunque español estaba luchando en una Brigada Internacional junto con italianos y rumanos. De la muerte de su tío conserva su tarjeta de pago (fig. 37) y un documento donde el Jefe de la XII Brigada "Garibaldi", Romano Marvin, y su Comisario, Eugenio Pacha, firmaban en Zalamea de La Serena su muerte en "Acción de guerra" el día 16 de febrero.

La muerte de este soldado no fue inscrita en el Registro Civil de Zalamea, aunque sí hay registradas muertes de soldados republicanos en las fechas anteriores y posteriores a los combates arriba descritos. Los últimos que aparecen fueron inscritos a mediados de marzo y pertenecían a la 63 Brigada $^{16}$. Precisamente gracias a esta fuente documental, los Libros de Defunciones del Registro Civil de Zalamea, hemos detectado una acción paralela, y plenamente conectada con las acciones desencadenadas en el Frente de guerra, que las fuerzas rebeldes realizaron con motivo de rechazar la contraofensiva republicana arriba relatada. Así, el 17 de febrero de 1938 aviones franquistas bombardearon el pueblo de Zalamea causando una matanza entre la población civil. Fueron asesinadas doce personas, de ellas ocho menores de edad, la más pequeña de tres años y la mayor de 20. La idea de la "guerra total" y la estrategia rebelde de propagar el terror a través de la violencia más indiscriminada contra la población se

\footnotetext{
${ }^{13}$ El teniente coronel Jefe de la 45 División en su oficio firmado desde Cabeza del Buey el 19 de febrero de 1938 describía las fuerzas rebeldes: "el enemigo movilizó sus reservas que fueron mayores de lo que se suponía, compuesta de tres Tabores de regulares, una Bandera del Tercio, el tercer Regimiento de Castilla, cinco escuadrones de caballería española y moruna, seis baterías, tanques y carros blindados". AGMAV. DR. Ejército de Extremadura. Estado Mayor. Operaciones. Informes sobre operaciones. Armario 62. Carpeta 10. Legajo 775.

${ }^{14}$ AGMAV. DR. Ejército de Extremadura. Estado Mayor. Operaciones. A. 62/C. 10/L. 775.

${ }^{15}$ AGMAV. DR. Ejército de Extremadura. A. 54/ C. 2/ L. 482/ D. 5.

${ }^{16}$ Registro Civil de Zalamea de La Serena. Libro de Defunciones.
} 


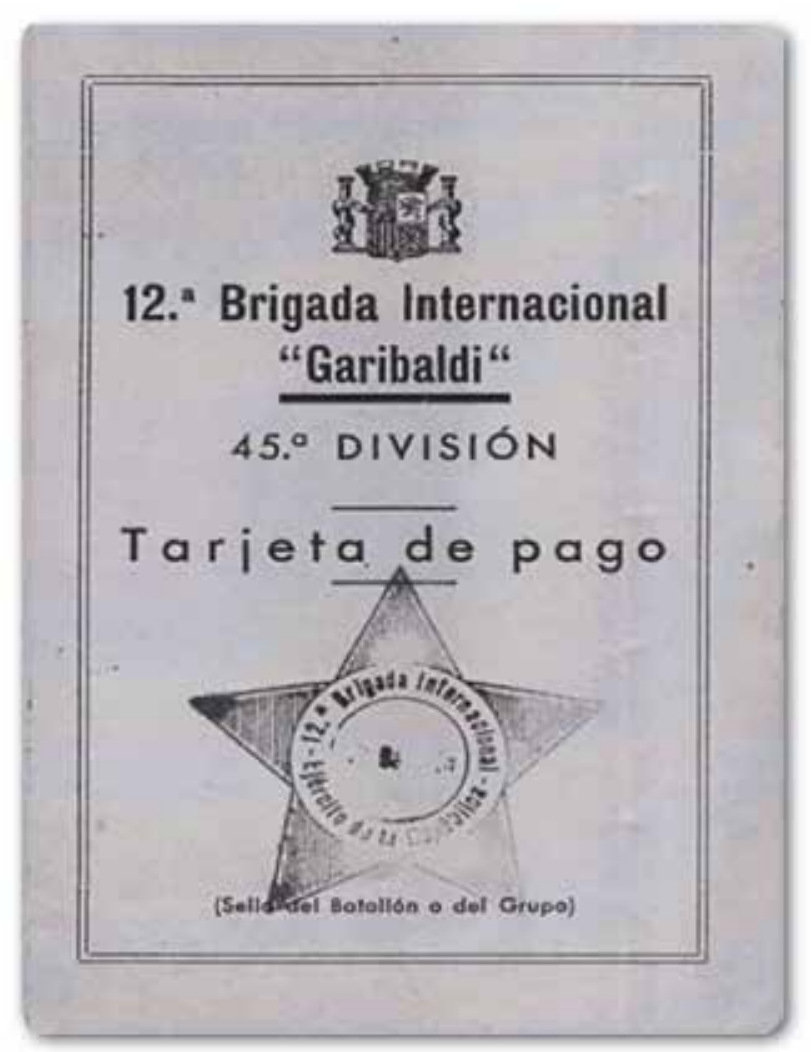

Fig. 37. Tarjeta de pago de la XII Brigada "Garibaldi. / Payment card of the XII Brigade "Garibaldi".

hicieron patentes en bombardeos de este tipo. Se castigaba la resistencia republicana tanto en la vanguardia, en el frente de combate, como en su retaguardia, en las calles y plazas de los pueblos.

Las fuerzas franquistas se preparaban para la ofensiva sobre los principales núcleos de población republicanos que, como hemos apuntado, venían preparando sus mandos desde meses atrás. A finales de julio de 1938 la mayoría de los pueblos de las Vegas Bajas del Guadiana y de La Serena iban a ser ocupados por las fuerzas rebeldes. Tras esa ocupación militar se iniciaría la primera fase de una implacable represión socio-política que empezaría a cimentar un régimen dictatorial que duró casi cuarenta años.

\section{CONCLUSIONES GENERALES}

El yacimiento arqueológico del Castillo del Argallén, del que hasta esta primera campaña de sondeos no existía una estratigrafía arqueológica, es conocido desde antiguo, siendo un referente espacial de primer orden, por su papel en distintos avatares históricos, especialmente durante la "reconquista" y posterior repoblación de estas comarcas, así como en la Guerra Civil.

Nos encontramos con indicios que avalan una dilatada secuencia cultural. En primer lugar, hay que hacer referencia a una serie de materiales, por su orden los más antiguos, que apuntan a una ocupación del sitio a caballo entre el mundo indígena y la romanización.

No obstante, la campaña de sondeos también nos ha permitido documentar la fundación de algunos de estos paramentos "ciclópeos" en época andalusí. De este modo, en ambos sondeos se ha constatado una ocupación intensa en este período, principalmente entre las Primeras Taifas y el mundo almohade, posiblemente hasta su absorción del sitio en territorio cristiano y su definitiva despoblación en el siglo XIII.

En el Sondeo A, las remociones contemporáneas para la provisión de mampuesto con motivo de la construcción de una trinchera con parapeto pétreo durante la Guerra Civil ocasionó la pérdida de una notable porción del paquete estratigráfico andalusí, mientras que en el Sondeo B, pudo localizarse un nivel de suelo dispuesto sobre la zapata, que también se documentó en el Sondeo A. No se localizó en estos dos sondeos ningún dato acerca de una continuidad del hábitat ya en período cristiano, hecho que corrobora la despoblación del sitio una vez ocupado el territorio por los cristianos, quedando este como punto del deslinde entre las Órdenes de Alcántara y Santiago. Así a la vista de toda la documentación aportada durante el periodo de excavación e investigación del sitio, queda clara la importancia que el "Algalet" andalusí en la Extremadura musulmana: un hisn semejante a los cercanos de Magacela, Hornachos o Benquerencia de La Serena. Y muestra de ello es la amplia dispersión de materiales cerámicos y de las numeras estructuras visibles, como murallas y posibles torres de gran entidad.

Finalmente, el lugar es testigo del último acontecimiento bélico, hecho que ha dejado una notable huella en el yacimiento. De esta forma, la remoción de tierra para obtener mampuesto con el que construir una trinchera y su parapeto ocasionó la creación de una especie de hoyo o cubeta que pudo ser utilizada como puesto de tirador, con una inmejorable visibilidad y dominio del entorno. Fue durante la excavación del Sondeo A cuando se pudieron documentar hallazgos materiales que indican la actividad en esta zona del Frente extremeño y la internacionalización que en armas y hombres tuvo el desarrollo de la Guerra en ambas trincheras, incluso en un frente secundario como el extremeño. La imposibilidad de dar una identidad al "soldado" exhumado, que tras su estudio fue inhumado en el Cementerio de Campillo de Llerena, nos muestra las carencias y debilidades del Estado Español hacia el pasado de nuestra guerra y postguerra, siendo necesaria una revisión y estudio de las políticas públicas de memoria y de gestión de "los Caídos" Ilevadas a cabo durante todo el franquismo.

Con todo, esta primera campaña de sondeos ha permitido una aproximación a la realidad arqueológica del Castillo del Argallén, obteniéndose así la lectura cronológica de un enclave situado en una encrucijada de sierras, valles y ríos, que en varias ocasiones ha puesto de relieve su posición estratégica. 


\section{BIBLIOGRAFIA}

Adrada Fernández, R., 1939. Manual del sargento de zapadores especialista en artillería. Zaragoza.

Aguado Benítez, R., 2004. Apuntes para el estudio del cementerio de los italianos de Campillo de Llerena. In: Mateos Ascacibar, F.J., Lorenzana de la Puente, F. (Coord.), Actas de las V Jornadas de Historia de Llerena, 141-158. Llerena.

Asociación Española de Coleccionistas de Cartuchería (AECC). http://www.municion.org/

Aufderheide, A.C., Rodríguez-Martín, C., Langsjoen, O., 1998. The Cambridge encyclopedia of human paleopathology 478 . Cambridge.

Barroso-Cabrera, J., Carrobles Santos, J., Morín de Pablos, J.L., Sánchez, I., Fraile, F.J., Rodriguez-Avello Luengo, L., Curado Morales, J.M., Criado Castellano, I., 2011. Arqueología de la Guerra Civil en Toledo. El frente sur del Tajo y el cigarral de Menores: un escenario de guerra. Archivo Secreto 5, 330-348.

Buikstra, J.E., Ubelaker, D.H., 1994. Standards for data collection from human skeletal remains. Arkansas Archeological Survey.

Chautón Pérez, H., 2016. La Guerra Civil en Aragón. Aproximación desde la perspectiva de la arqueología. La Linde, 6.

Duday, H., 1997. Antropología biológica "de campo", tafonomía y arqueología de la muerte. In: Malvido, E., Pereira, G., Tiesler, V. (Coord.), El cuerpo humano y su tratamiento mortuorio, 91-126. Centro de estudios mexicanos y centroamericanos, Consejo Nacional para la Cultura y las Artes, Instituto Nacional de Antropología e Historia (INAH), Mexico.

Engel, C., 2000. Historia de las Divisiones del Ejército Nacional 1936-1939. Almena Ediciones, Madrid.

Engel, C. 2005. Historia de las Brigadas Mixtas del Ejército Popular de la República 1936-1939. Almena Ediciones, Madrid.

Etxeberría Gabilondo, F., Herrasti L., 2014. Informe de exhumación de un combatiente en Lemoatz (Lemoa, Bizkaia). Aranzadi Zientzia Elkartea, Donostia.

Etxeberría Gabilondo, F., 2004. Panorama organizativo sobre Antropología y Patología Forense en España. Algunas propuestas para el estudio de fosas con restos humanos de la Guerra Civil española de 1936. In: La memoria de los olvidados: un debate sobre el silencio de la represión franquista, 183-219.

Fortuna, M., Mezquida, M., Martínez, A., Calpe, A., Iglesias-Bexiga, J., Benito, M., Mora, T., Coch, C., Muñoz, A., Sánchez, J.A. (e.p.): "Enterramiento de soldados exhumados en el Frente de Levante". (pendiente de publicar).

Galloway, A., Wedel, V., 2014. Common circumstances of blunt force trauma". Broken Bones 2, 91-125.

Gibello Bravo, V.M., 2006. El poblamiento islámico en Extremadura: Territorio, asentamientos e itinerarios. Junta de Extremadura, Mérida.

González-Ruibal, A., 2012. El último día de la Batalla del Ebro. Informe de las excavaciones arqueológicas en los restos de la Guerra Civil de Raïmats, La Fatarella (Tarragona). Disponible en: http://digital.csic.es/bitstream/10261/47780/1/2012_Informe\%20La\%20Fatarella\%202011_Gonzalez.pdf.

González-Ruibal, A., 2010. Arqueología de la Guerra Civil Española en el Frente de Guadalajara. Informe de las excavaciones arqueológicas en los restos de la Guerra Civil en el Castillo de Abánades. Centro Superior de Investigaciones Científicas.

González-Ruibal, A., 2016. Volver a las trincheras. Una arqueología dela Guerra Civil Española. Alianza editorial.

Haglund, W.D., Sorg, M.H., 2002. Advances in Forensic Taphonomy, method, theory and archaeological perspectives. CRC Press.
Harris, E.C., 1991. Principios de Estratigrafía Arqueológica. Barcelona.

Herrasti, L, Sampedro, A.J., Diéguez, J, Etxezarraga, J., Irusta, A., Jiménez, J., Rebolledo, I., Sardon, A., Sardon, E., Etxeberría, F., 2014. Placas de identificación de combatientes de la Guerra Civil española (1936-1937), recuperadas en exhumaciones de escenarios bélicos en el País Vasco. Munibe Antropologia-Arkeologia 65, 289-312.

Hillson, S.W., 2000. Dental pathology. In: Katzenberg, M.A., Saunders, S.R. (Eds.), Biological anthropology of the human skeleton, 249-286. New York.

Hinojosa Durán, J., 2006. Notas sobre la vida cotidiana de la tropa republicana en un frente secundario. Los soldados republicanos en el Frente Extremeño durante el segundo semestre de 1937. In: Congreso Internacional de la Guerra Civil Española, Madrid. Disponible en: http://studylib.es/doc/6184809/ notas-sobre-la-vida-cotidiana-de-la-tropa-republicana-en-...

Hinojosa Durán, J., 2007. Tropas en un frente olvidado. El ejército republicano en Extremadura durante la Guerra Civil. Editora Regional de Extremadura, Mérida.

Hinojosa Durán, J., 2008. El hundimiento del Frente Extremeño en el verano de 1938. In: Actas Jornadas Guerra y Patrimonio en el Frente Extremeño. 70 aniversario del cierre de la "Bolsa de La Serena", 29-89, CEDER "La Serena", Badajoz.

Hinojosa Durán, J., 2010. Miguel Hernández y los combatientes republicanos en Extremadura durante la Guerra Civil. In: Frente Extremeño. Periódico del Frente de Extremadura en la Guerra Civil Española. Castuera, junio-julio de 1937. Tomo I. Diputación de Badajoz.

Hinojosa Durán, J., 2012. José Ruiz Farrona, un militar profesional republicano en el Frente Extremeño durante la Guerra Civil". In: Chaves Palacios, J. (coord.), Política y sociedad durante la Guerra Civil y el Franquismo: Extremadura, 617-636. Diputación de Badajoz.

Iglesias-Bexiga, J., Benito, M., Fortuna, M., Muñoz, A., Domínguez, R., Sánchez, J.A., 2014. Estudio de los restos óseos pertenecientes a dos soldados exhumados en el Frente de Levante, Sierra de El Toro (Castellón). In: Actas de la $6^{a}$ Reunión científica de la Asociación Española de Antropología y Odontología Forense.(Pendiente de publicar).

Kimmerle, E.H., Baraybar, J.P., 2008. Skeletal trauma. Identification of Injuries Resulting from Human Rights Abuse. CRC Press.

Krenzer, U., 2006. Compendio de métodos antropológico forenses para la reconstrucción del perfil osteo-biológico: Estimación de la edad osteológica en subadultos. CAFCA, Centro de Análisis Forense y Ciencias Aplicadas.

Krogman, W.M., Iscan, M.Y., 1986. The Human Skeleton in Forensic Medicine. SpringWeld.

Lombardo Sáenz, A., 2011-2012. El Cementerio de los italianos de Campillo de Llerena como lugar de la memoria. Universidad de Zaragoza. Máster interuniversitario de Historia Contemporánea, curso 2011/2012. Tutora: Ángela Cenarro Lagunas. Disponible en: http://zaguan.unizar.es/record/9665/ files/TAZ-TFM-2012-1181.pdf

López Fraile, F.J., Morín de Pablos, J., Rodriguez Fernandez, A., 2008. La Batalla de Madrid (1936-39). Excavaciones en las defensas de la capital. Complutum 19(2), 47-62.

Martínez Barrio, C., Alonso Muela, A.L., 2014. Excavaciones arqueológicas en los restos de la Guerra Civil en Abánades (Guadalajara). Campaña de 2012. Informe Antropológico.

Mezquida, M. (e.p.). "Arqueología del entramado defensivo republicano al sur del Mijares en Olba (Teruel)". (pendiente de publicar).

Martínez Bande, J.M., 1981. La Batalla de Pozoblanco y el cierre de la Bolsa de Mérida. Servicio Histórico Militar, Madrid. 
Moreno Gómez, F., 2013. Trincheras de la República, 19371939. Desde Córdoba al Bajo Aragón, al destierro y al olvido. La gesta de una democracia acosada por el fascismo. El Páramo, Córdoba.

Moreno Gómez, F., 2015. Aldo Morandi en España. Libro-catálogo de la Exposición de fotos inéditas de la guerra civil, s. el archivo privado del jefe brigadista internacional Aldo Morandi. El Autor, Villanueva de Córdoba.

Ortiz Romero, P., 1991. Excavaciones y sondeos en los recintos tipo torre de La Serena". I Jornadas de Prehistoria y Arqueología en Extremadura. Extremadura Arqueológica II, 301318. Mérida-Cáceres.

Ortner, D.J., 2003. Identification of pathological conditions in human skeletal remains. Academic Press.

Penedo Cobo, E., Sanguino Vazquez, J., Rodríguez Morales, J, Marañón López, J., Martinez Granero, A.B., 2008. Arqueología de la Batalla del Jarama". Complutum 19(2), 63-87.

Penedo, E., Sanguino, J., Etxeberria, F., Herrasti, L., Bandres, A., Albisu, C., 2009. Restos humanos del Frente del Jarama en la Guerra Civil 1936-1939". Munibe Antropologia-Arkeologia 60, 281-288.

Reverte, J.M., 1984. Informe emitido por la Escuela de Medicina Legal de Madrid en su sección de Antropología Forense al IImo. Sr. Juez del Juzgado de instrucción $n^{\circ} 10$ de Madrid: Los esqueletos de la Casa de Campo de Madrid. Anales de la Escuela de Medicina Legal de la Universidad Complutense de Madrid 1, 33-48.
Rodríguez Díaz, A., Pavón Soldevila, I, Duque Espino, M.D., 2012. El poblado prerromano de entrerríos (Villanueva de la Serena, Badajoz). Campaña de 2008. Mérida.

Sanabria Murillo, D., Sánchez Hidalgo, F., Gibello Bravo, V.M., Menéndez Menéndez, A., 2013. Nuevos datos para el conocimiento de la Segunda Edad del Hierro en la Baeturia Túrdula. El yacimiento de El Espadañar (Quintana de la Serena, Badajoz). In: VI Encuentro de Arqueología del Suroeste peninsular. Villafranca de los Barros.

Torres-Martinez, J.F., Domínguez-Solera, S.D., 2008. Monte Bernorio (Palencia): siglo I a.C. / 1936- 1937 d.C. Arqueología de un campo de batalla. Complutum 19(2), 103-117.

\section{FUENTES DOCUMENTALES}

- Archivo General Militar de Ávila.

- Ayuntamiento de Zalamea de La Serena. Registro Civil.

- BOE 232, 27-09-2011.

- Centro Documental de la Memoria Histórica (Salamanca). 
